\title{
Interactions between payments for hydrologic services, landowner decisions, and ecohydrological consequences: synergies and disconnection in the cloud forest zone of central Veracruz, Mexico
}

\author{
$\underline{\text { Heidi Asbjornsen }}^{1}$, Robert H. Manson $^{2}, \underline{\text { Jason J. Scullion }}^{3}$, Friso Holwerda $^{4}$, Lyssette E. Muñoz-Villers $^{4}, \underline{\text { M. Susana Alvarado- }}^{2}$ \\ Barrientos $^{5}$, Daniel Geissert ${ }^{2}$, Todd E. Dawson ${ }^{6}$, Jeffrey J. McDonnell ${ }^{7}$ and L. Adrian Bruijnzeel $^{8}$
}

\begin{abstract}
Payments for Hydrologic Services (PHS) programs are increasingly used as a policy tool to provide incentives for upstream landowners to adopt land use activities that favor sustainable provision of high-quality water to downstream areas. However, the effectiveness of PHS programs in achieving their objectives and the potential for unintended (often undesirable) consequences remain poorly understood. We integrate results from ecohydrological and socioeconomic research to explore the impact of Mexico's PHS program on the target hydrologic services and people's decisions, behavior, and knowledge regarding forest conservation and water. Using central Veracruz as our case study, we identify areas of both synchrony and disconnection between PHS goals and outcomes. Mature and regenerating cloud forests (targeted by PHS) were found to produce enhanced hydrologic services relative to areas converted to pasture, including reduced peak flows during large rain events and maintenance of dry-season base flows. However, unexpectedly, these hydrologic benefits from cloud forests were not necessarily greater than those from other vegetation types. Consequently, the location of forests in strategic watershed positions (e.g., where deforestation risk or hydrologic recharge are high) may be more critical than forest type in promoting hydrologic functions within watersheds and should be considered when targeting PHS payments. While our results suggest that participation in PHS improved the level of knowledge among watershed inhabitants about forest-water relationships, a mismatch existed between payment amounts and landowner opportunity costs, which may contribute to the modest success in targeting priority areas within watersheds. Combined, these findings underscore the complexity of factors that influence motivations for PHS participation and land use decisions and behavior, and the importance of integrating understanding of both ecohydrological and socioeconomic dynamics into PHS design and implementation. We conclude by identifying opportunities for improving the design of PHS programs and recommending priority areas for future research and monitoring, both in Mexico and globally.
\end{abstract}

Key Words: deforestation; interdisciplinary research; payments for ecosystem services; tropical montane cloud forests; watershed management and sustainability

\section{INTRODUCTION}

Water scarcity and declining water quality are two of the most critical environmental problems facing societies worldwide (Postel et al. 1996, Johnson et al. 2001, Brauman et al. 2007). A potential solution that has gained popularity in recent years is the use of payment (or compensation) mechanisms to create economic incentives for protecting forests and their hydrologic services that are equal to or greater than the opportunity costs foregone by limiting land use options. If successful, such approaches, referred to here as "payments for hydrologic services" (PHS), could vastly improve the supply, quality, and regulation of water resources globally.

Payments for hydrologic services policies operate at the interface between society and the environment because they are designed to enhance the services provided by biophysical systems by eliciting certain desirable behaviors from social systems through incentives that target associated economic systems. Interactions and feedbacks between PHS policies and society may be further amplified by other unintended socioeconomic effects, such as inequities in access to or distribution of economic or environmental resources (Wunder and Alban 2008, Daw et al. 2011), and through impacts on other ecosystem services, such as carbon sequestration, biodiversity, and nontarget hydrologic services (Martínez et al. 2009, Wendland et al. 2010). Such unintended consequences of PHS policies can lead to complex synergistic or antagonistic interactions that often produce unexpected outcomes - both for hydrologic services and societal well-being (Jenerette et al. 2006, Porras et al. 2008).

Despite calls for greater monitoring and assessment of PHS programs (Wunder 2007, Jack et al. 2008, Nelson et al. 2008), evaluation of their effectiveness in achieving their goals has lagged. One reason for this is that hydrologic services are inherently difficult to quantify, and the data collection and analysis required to provide meaningful information are generally beyond the temporal and financial scope of most PHS programs (Brouwer et al. 2011). Moreover, the scientific evidence documenting the relationship between forest cover and hydrologic services (notably flood mitigation and dry-season flows) tends to be highly site-specific and variable, often precluding the identification of general patterns (Kaimowitz 2004, Bradshaw et

${ }^{1}$ University of New Hampshire, ${ }^{2}$ Instituto de Ecología, A.C., ${ }^{3} \mathrm{McDaniel}$ College, ${ }^{4}$ National Autonomous University of Mexico, Center for Atmospheric Sciences, ${ }^{5}$ CONACYT - El Colegio de la Frontera Sur, ${ }^{6}$ University of California-Berkeley, Departments of Integrative Biology and Environmental Science, Policy \& Management, ${ }^{7}$ University of Saskatchewan, Global Institute for Water Security, Saskatoon, Canada, ${ }^{8}$ King's College London, Department of Geography, London, UK 
al. 2007, Lele 2009, Van Dijk et al. 2009). In one of the most comprehensive reviews of PHS programs to date, Brouwer et al. (2011) conducted a meta-analysis of 47 PHS schemes worldwide. They reported that $70 \%$ of the schemes used forest cover as a proxy for hydrologic services to evaluate performance, while only $47 \%$ of those schemes directly monitored relevant hydrologic variables. Although 58\% of those PHS schemes were classified as effective in reaching their objectives, this determination was based almost exclusively on program managers' opinions due to insufficient empirical data. A survey of 60 PHS schemes in Mexico showed that only about $50 \%$ conducted monitoring of forest cover, and a much smaller fraction (5\%) actually monitored effects on water quantity or quality (Saldaña-Herrera 2013). Clearly, a critical need exists for more robust monitoring of PHS schemes to establish reliable baseline conditions and quantify program effects on hydrologic services over time (Wunder 2007, Brouwer et al. 2011).

A strategy often used to enhance PHS effectiveness is to target particular ecosystem types or landscape locations that are considered to be hydrologically important. For example, some PHS schemes (Quintero et al. 2009: Ecuador; Muñoz-Piña et al. 2008: Mexico) attribute greater hydrologic value and, in turn, payment compensation to cloud forests because of their (presumably) higher water yield over other forests due to a combination of high rainfall, additional fog deposition inputs, and low evapotranspiration losses (cf. Bruijnzeel et al. 2011). Other programs have attempted to identify areas of greater hydrologic priority based on recharge zones (Peñuela-Arévalo and Carrillo-Rivera 2013). Deforestation risk - the probability that a forest will be converted to other land uses due to factors such as proximity to roads, slope, and opportunity costs - is often used to target payments to areas that maximize program additionality (i.e., the additional benefits obtained with PHS versus without PHS) (Muñoz-Piña et al. 2008). However, few studies have determined to what extent different approaches to targeting PHS payments have actually improved hydrologic service benefits.

The effectveness of PHS also depends directly on the ability to influence participants' land use behaviors in ways that conserve forests and achieve hydrologic goals (Engel et al. 2008). Studies suggest that PHS programs can enhance social well-being through, for example, strengthening individual property rights (Porras et al. 2008), creating new institutions to represent community interests (Pagiola et al. 2005), and increasing personal incomes (Greig-Gran et al. 2005). However, studies have also suggested that in some cases, PHS can lead to unintended social impacts that may reduce program effectiveness (Pagiola et al. 2005, Jack et al. 2008, Porras et al. 2008, Scullion et al 2011). Understanding how PHS programs produce unintended social impacts on participants and communities requires further attention on how PHS programs influence people's decisions, behavior, and knowledge regarding forest conservation and water resources, and the implications for PHS performance (Balmford and Bond 2005, Guariguata and Balvanera 2009, Orlove and Caton 2010, Hayes 2012). For example, knowledge of PHS rules, objectives, and scientific basis can affect participants' level of commitment to and engagement in conservation activities (Kosoy et al. 2007) and their land use behavior if the payments end (Fisher 2012). Also, a myriad of factors other than economic incentives, such as individual perceptions, values, culture, and social norms, may also be important motivations for PHS participation (Chen et al. 2009, Petheram and Campbell 2010, Fisher 2012, Bremer et al. 2014). For instance, if participants with low opportunity costs to conserve their forests enroll in PHS programs, program effectiveness may be reduced (Martin Persson and Alpizar 2013). Moreover, how PHS programs are designed and implemented, including the form of compensation (e.g., cash versus technical assistance or financing for sustainable land use practices), can strongly impact who participates, how long they participate, and their knowledge accumulation (Chen et al. 2009, Fisher 2012, Kaczan et al. 2013). In summary, PHS program effectiveness may be tightly linked to the social incentives and impacts produced by PHS programs, and understanding these relationships promises new insights to optimize the design of PHS programs.

The increasing scrutiny of PHS schemes in recent years stems from both uncertainty about effectiveness in achieving their goals and growing recognition of the often unintended consequences for the associated ecological and socioeconomic systems (Daw et al. 2011, Goldman-Benner et al. 2012, Asbjornsen et al. 2015). Understanding and predicting the dynamic relationship between PHS policies, the environment, and society is critical to guiding policy decisions in ways that maximize benefits and minimize costs (Goldstein et al. 2012). We use Mexico's 14-year experience with PHS as a model for exploring PHS impacts on both target hydrologic services and people's decisions, behavior, and knowledge regarding forest conservation and water resources.

Mexico's national PHS program was initiated in 2003 in response to the growing - and presumably linked-problems of deforestation and water scarcity (Manson 2004, Muñoz-Piña et al. 2008). Administered by Mexico's National Forestry Commission (CONAFOR), PHS was envisioned as a mechanism for providing financial incentives to landowners to conserve forests within eligible watersheds that were identified on the basis of the presence of priority ecosystems, proximity to national parks and downstream cities, degree of aquifer overexploitation, and overlap with poverty alleviation programs (see Alix-Garcia et al. 2005 and Muñoz-Piña et al. 2008 for details). Forested areas with at least $80 \%$ intact canopy cover are eligible for enrollment, including reforested and naturally regenerating lands. Furthermore, cloud forests receive between $81 \%$ and $>250 \%$ greater economic compensation over other forest types (Manson et al. 2013). Once approved, landowners sign a 5-year contract, and payments are canceled if a decrease in forest cover is detected via remote sensing. In 2008, CONAFOR created a second "matching funds" PHS program that differs from the national program by requiring at least $50 \%$ of program financing to come from local sources. While the national program funds only forest conservation and technical support, the matching programs can also support ecological restoration, monitoring of hydrologic services, and both cash and in-kind contributions for sustainable land use practices, and gives local program operators greater autonomy over deciding whom and where to pay, and how much.

Two fundamental premises underlie Mexico's PHS programs. First, the programs assume a positive relationship between the extent of forest cover (particularly cloud forest) and provisioning of hydrologic services. Second, they anticipate that payments will have a direct positive impact on people's decisions and behavior relative to forest conservation. Notwithstanding, several studies 
have recently questioned the social, economic, and environmental effectiveness of Mexico's PHS program and highlighted the need for deeper analysis and knowledge (Scullion et al. 2011, MuñozPiña et al. 2011, Shapiro-Garza 2013). Moreover, Brouwer et al. 's (2011) meta-analysis rated Mexico's national PHS program as "ineffective" due to the large amount of uncertainty expressed by program administrators and other key informants regarding its additionality and impacts on hydrologic services. Another study found that although payments were successful in reducing deforestation rates, additionality was likely low due to overall low deforestation risk in payment areas (Alix-Garcia et al. 2014).

We focus our analysis of Mexico's PHS program in Veracruz, which is one of the most deforested states in Mexico and has historically experienced problems with lowland flooding (LópezRodriguez and Acevedo-Rosas 2005, Ellis et al. 2012), as well as threats from climate change-induced increases in both flooding and water shortages (Tejeda-Martínez 2005). The region is second only to Mexico City in terms of poor drinking water quality, and is also experiencing an expanding hypoxia zone in the Gulf of Mexico (Yáñez-Arancibia and Day 2004). Our work was conducted within two adjacent watersheds (Fig. 1) that are the major water source for two large population centers with active local PHS programs: Los Gavilanes ( 4000 ha; Coatepec City, population $=79,787$; receives $90 \%$ of its water from the Los Gavilanes River) and Pixquiac ( 10,727 ha; Xalapa City, population $=457,928$; receives $40 \%$ of its water from the Pixquiac River) (García-Coll et al. 2004, INEGI 2011, Paré and Gerez 2012). The upland regions of both watersheds are covered by mixed pine-oak forests at the highest elevations ( $>2500 \mathrm{~m}$ above sea level [asl]), while cloud forests dominate at mid-elevations (1200-2500 $\mathrm{m}$ asl). More than $64 \%$ of the area has been deforested and converted to other land uses, primarily pasture and agricultural lands (Muñoz-Villers and López-Blanco 2008). Consequently, this region meets several of the PHS enrollment criteria, including the presence of priority ecosystems, proximity to downstream cities, and water scarcity issues. Mexico's first pilot PHS program, FIDECOAGUA, was established in 2002 by the municipality of Coatepec, whereas Mexico's national PHS program started operating in both the Los Gavilanes and Pixquiac watersheds in 2003. Payments for hydrologic services were later expanded with the creation of the PROSAPIX program by the municipality of Xalapa and a local NGO in the Pixquiac watershed in 2006. Both FIDECOAGUA and PROSAPIX transitioned to CONAFOR's matching funds program in 2008, which left relatively few payments from the national program in these watersheds thereafter. Due to their similar approach and extensive overlap, we consider these programs under the common umbrella of PHS, unless otherwise specified.

We present a synthesis of the results from a large, long-term interdisciplinary research effort aimed at assessing the effectiveness of Mexico's PHS programs in achieving its water resource and forest conservation, and exploring potential social impacts in central Veracruz. Specifically, we addressed the following questions: (1) Does valuing cloud forests over other land cover types by Mexico's PHS programs enhance hydrologic services? (2) Is Mexico's PHS program effective at targeting hydrologic recharge zones within watersheds? (3) Is Mexico's PHS program successful at targeting areas of greatest deforestation risk for PHS enrollment? (4) Does Mexico's PHS program produce social impacts that reduce the program's effectiveness? To answer the first question, we integrated findings from our previous ecohydrological research, while the subsequent questions build upon this previous work and are addressed through a combination of original and previous research conducted in the same study area. In cases where findings have not been previously published, we describe the methods in detail; otherwise, a brief summary and relevant citations are provided. We then synthesize our findings to examine the degree of congruence between Mexico's PHS policies, hydrologic services, and participant responses, and to help determine the degree of synchrony (or disconnect) between the policy and desired outcomes. This novel integration of diverse biophysical and social science data provides new insights about the complex socioenvironmental dynamics impacting-and influencing-PHS policies. We conclude by offering specific recommendations for future improvements to PHS programs, and identifying priority areas for research and monitoring, in Mexico and globally.

Fig. 1. Map comparing areas of different levels of net recharge with those receiving payments for hydrologic services (PHS) from the national (diagonal line shading) and local matching programs (grey shading) during the period 2003-2011 in the Pixquiac and Gavilanes watersheds. Also shown is the location of these watersheds in the large Antigua River basin and the state of Veracruz, Mexico (lower left corner).

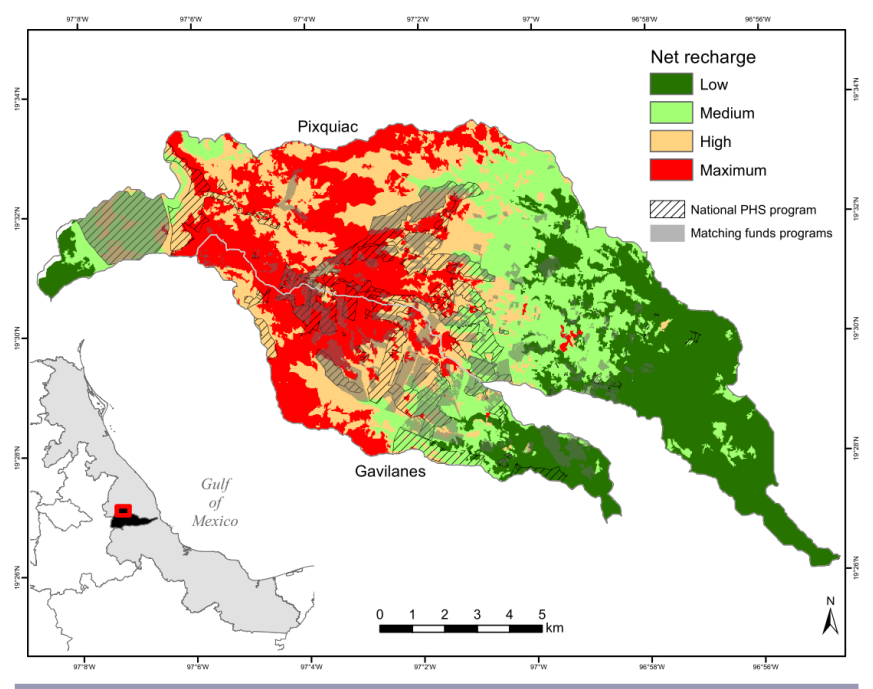

Does valuing cloud forests over other land cover types by Mexico's Payments for Hydrologic Services program enhance hydrologic services?

Tropical montane cloud forests are broadly defined as forests that are influenced by the "frequent presence of cloud or mist" (Stadtmüller 1987). Despite making up only $1.4 \%$ of the world's tropical forests (and $6.6 \%$ of tropical montane forests) (Scatena et al. 2010), cloud forests are widely recognized for their high levels of biodiversity and endemism, but it is the perceived hydrologic services of cloud forests that have often attracted the greatest attention (Bubb et al. 2004, Bruijnzeel et al. 2010). Cloud forests can deliver large amounts of stream water due to a combination of high rainfall, additional water inputs from cloud water interception by the canopy (CWI), and low evapotranspiration 
(ET) losses due to greatly reduced vapor pressure gradients (Zadroga 1981, Brown et al. 1996, Caballero et al. 2013). However, not all cloud forests are functionally equal (Scatena et al. 2010), and their water yield varies as a function of geographic differences in, especially, climate and exposure to fog and wind (Jarvis and Mulligan 2011). For instance, observed annual amounts of CWI range from $22 \mathrm{~mm}$ to $1990 \mathrm{~mm}$, and modeled contributions of CWI vary from $5 \%$ to $>75 \%$ of annual precipitation $(P)$, while annual ET can range from $<550 \mathrm{~mm}$ to $>1280 \mathrm{~mm}$ (Bruijnzeel et al. 2011 and references therein).

We examined the ecohydrology of a mature and a regenerating cloud forest and the effects of cloud forest conversion to pasture and pine plantations on annual water yield and flow regulation in the upland region of the Los Gavilanes watershed in central Veracruz (see Muñoz-Villers et al. 2015 for detailed site descriptions). We found that additional water inputs due to CWI were comparatively low $\left(<2 \%\right.$ of $3180 \mathrm{~mm} \mathrm{yr}^{-1}$ and $8 \%$ of dryseason rainfall of $640 \mathrm{~mm}$ ), which was largely attributed to the relatively infrequent occurrence of dense fog and, especially, low wind speeds (Holwerda et al. 2010, Alvarado-Barrientos et al. 2014). Our cloud forest site falls at the low end of the global range for CWI, while the estimated ET (1325 $\mathrm{mm} \mathrm{yr}^{-1}$ ) (Muñoz-Villers et al. 2012) is at the higher end of the global range (Bruijnzeel et al. 2011). These findings contrast with many other studies conducted in (foggier or windier) cloud forest sites that showed a much greater annual water recharge (i.e., CWI inputs minus ET losses) (Holwerda 2005, Holwerda et al. 2006, Bruijnzeel et al. 2006, McJannet et al. 2007). This high global variability in CWI inputs, ET losses, and thus water yield underscores the fact that not all cloud forests are hydrologically similar and that sitespecific analyses are critical to accurately assess their water production services relative to other important ecosystem services (cf. Bruijnzeel et al. 2010, Cingolani et al. 2015).

Our findings further suggest that valuing and protecting cloud forest over shorter vegetation types, such as pasture, is not likely to increase total annual water yield but should increase critical dry-season flows. The lower ET rates typical of grassland and shrub vegetation compared to forests in the same environment generally result in higher net annual water yield (e.g., Zhang et al. 2004), unless additional water inputs afforded by CWI are greater than the difference in ET between vegetation types (e.g., Bruijnzeel et al. 2006). This was confirmed in our Veracruz study, as the estimated annual ET of pasture $(825 \mathrm{~mm})$ was much lower than that of nearby mature cloud forest $(1325 \mathrm{~mm})$ or 20 -yearold regenerating cloud forest $(1059 \mathrm{~mm})$. Consequently, for a mean annual precipitation $(\mathrm{P})$ of ca. $3000 \mathrm{~mm}$, water yield $(\mathrm{P}+$ CWI - ET) was much higher for pasture $(2185 \mathrm{~mm}$; with negligible CWI) than for mature cloud forests $(1730 \mathrm{~mm}$; with annual CWI $=45 \mathrm{~mm})$ or regenerating cloud forests $(1985 \mathrm{~mm}$; with annual CWI $=38 \mathrm{~mm}$ ) (Muñoz-Villers et al. 2015). Despite higher annual water yield, baseflows from the pasture during the late dry season were $35 \%$ and $70 \%$ lower than flows from the mature and regenerating cloud forests, respectively; these differences were attributed to a combination of lower topsoil infiltration capacity, gentler topography, and lower soil and groundwater storage capacity in the pasture compared to the forested catchments (Muñoz-Villers and McDonnell 2013). Maintaining dry-season baseflow is a critical hydrologic service for downstream communities, which in the past, have experienced water scarcity during very dry years in Veracruz (Tejeda-Martínez 2005).

Forests are also considered important for mitigating excessive peak flows that can lead to downstream flooding (e.g., Bradshaw et al. 2007), although this contention has been subject to much debate (Alila et al. 2009, 2010, Van Dijk et al. 2009, Lewis et al. 2010). Forest conversion to more intensive forms of land use is often accompanied by soil compaction and degradation, which can reduce infiltration rates and increase rainfall-runoff responses (Molina et al. 2007, Zimmermann and Elsenbeer 2009, Bathurst et al. 2011, Ghimire et al. 2013). At our Veracruz site, despite generally higher topsoil bulk density and much lower saturated hydraulic conductivity under pasture compared to regenerating and mature cloud forests $(0.49 \pm 0.06,0.45 \pm 0.11$, and $0.25 \pm 0.17$ $\mathrm{g} \mathrm{cm}^{-3}$, and $30 \pm 14,615 \pm 690$, and $777 \pm 931 \mathrm{~mm} \mathrm{~h}^{-1}$, respectively) (Muñoz-Villers et al. 2015), prevailing rainfall intensities at this elevation rarely exceeded topsoil infiltration capacities to generate flood-producing rates of overland flow (Muñoz-Villers and McDonnell 2013). However, during the largest rainfall events, peak flows from the pasture catchment were up to two times greater than those from the forested catchments (Muñoz-Villers and McDonnell 2013), which suggests that beyond some threshold of rainfall amount and intensity, cloud forests would provide important hydrologic buffering against flooding. The moderating influence of cloud forests on peak flows and dryseason baseflows may become even more important in the future because climate change forecasts for Veracruz predict an increase in the frequency and intensity of extreme weather events (TejedaMartinez 2009, Bender et al. 2010).

Most other studies that have examined impacts of land use change on hydrologic services in cloud forest regions were based on modeling rather than empirical field data, and have reached varying conclusions. For instance, Quintero et al. (2009) reported that watersheds with native cloud forest and páramo vegetation in the Ecuadorian Andes produced slightly lower annual water yield than those dominated by agriculture, while greater water infiltration under cloud forest resulted in greater aquifer recharge and lateral flow leading to enhanced dry-season flow $(0.5 \%$ over a decade). Conversely, in wet and windy northern Costa Rica, modeling simulations based on detailed hydrological process measurements predicted that conversion of cloud forest to rough pasture would have a more or less neutral impact on annual or seasonal flows despite a substantially greater CWI at this site compared to our Veracruz site (Bruijnzeel et al. 2006, Schellekens 2006). This near-neutral result was attributed to the combined compensatory effect of a lower ET for pasture (leading to higher flows) and a comparatively small difference in CWI for cloud forest versus aerodynamically rough pasture (lower under the latter, leading to reduced flows). Another modeling-based study conducted in a cloud forest region in central Costa Rica also found that while conversion of catchments from primarily forest to pasture had relatively little effect on mean annual water yield (< $3 \%$ ), forested catchments had lower runoff peaks and higher dryseason flows by up to $10 \%$ on short time scales $(<1$-year return period) (Birkel et al. 2012). This ability of forests to provide protection was not maintained for large return interval floods $(<$ 1 -year return period). More work is needed to better quantify the potential of forests to regulate hydrologic flows and mitigate 
flooding, and especially to identify thresholds in relation to the required proportion and location of forest cover, for different soil and geologic properties and rainfall intensities (recent work suggests that rainfall intensity is more important for runoff generation in forested catchments than was previously thought) (Janzen and McDonnell 2015).

Once canopy closure and full site occupancy occurs following a disturbance, young, vigorously regenerating forests generally have much higher ET rates compared to mature forests. Consequently, annual streamflow typically declines during early stages of forest regeneration, and gradually returns to predisturbance conditions as ET decreases with forest maturation (Hornbeck et al. 1993, Vertessy et al. 2001, Bruijnzeel 2004). In contrast to this typical pattern, the 20-year-old regenerating (postfire) cloud forest examined in our Veracruz study had similar transpiration as the mature cloud forest but lower annual ET. This finding was attributed to the greater rainfall interception by the canopy of mature cloud forest, which, in turn, was due to its greater abundance of canopy epiphytes and higher leaf area index (Holwerda et al. 2010, Muñoz-Villers et al. 2012), similar to findings reported by Fleischbein et al. (2005) for an Ecuadorian montane forest. Interestingly, peak flows and seasonal distribution of flows from catchments that supported mature versus regenerating cloud forest were indistinguishable (MuñozVillers and McDonnell 2013), which suggests similar hydrologic behavior. Consequently, Mexico's current policy of allowing PHS enrollment of regenerating forests may effectively promote hydrologic functions similar to those of mature cloud forest. Additional research on regenerating cloud forests of different ages and degree of soil disturbance is needed to fully assess the associated impacts on hydrologic flows over time and under varying soil conditions (cf. Zimmermann et al. 2013).

The impact of reforestation on hydrologic services is particularly controversial (e.g., Liu et al. 2008, Paruelo 2012, Vihervaara et al. 2012). Much of the concern stems from numerous studies that have documented higher water use and, consequently, lower water yield following tree planting (often with exotic species) on former grasslands (see Farley et al. [2005] for a global review and Scott et al. [2005] for a review of tropical and degraded sites), while much less is known about the consequences of planting native species on former forested lands (Nogueira et al. 2004, Dierick and Hölscher 2009). In Veracruz, Pinus patula, a species native to the region's highlands (above the cloud forest zone), is widely planted within the cloud forest zone as part of reforestation efforts. Our Veracruz study showed that a young 10 -year-old $P$. patula plantation had almost $20 \%$ lower stand-level transpiration than nearby mature and 20-year-old regenerating cloud forest, whereas a mature, selectively harvested pine plantation had more than $60 \%$ lower stand-level transpiration than mature cloud forest (Alvarado-Barrientos 2013, Muñoz-Villers et al. 2015). Moreover, since rainfall interception by the two plantation forests was also lower, their overall ET was substantially less than that for mature and regenerating cloud forests (Muñoz-Villers et al. 2015). Surprisingly, we also found that ET of the young and mature pine forests was similar to and less than that of pasture, respectively (Muñoz-Villers et al. 2015). In addition to the relatively sparse canopy of mature $P$. patula trees, the relatively low ET in the mature P. patula stand was in part attributable to previous selective logging activities that had reduced stand basal area. Thus, from a purely hydrologic services standpoint, planting of native pine trees on degraded pasture areas at this site did not produce a dramatic increase in ET or reductions in water yield, in contrast to findings reported elsewhere (Farley et al. 2005, Buytaert et al. 2007, Huber et al. 2008, Wang et al. 2008, Little et al. 2009). Notwithstanding, the higher infiltration rates recorded for pine stands versus grazed pasture suggests a positive impact of pine reforestation on soil hydraulic properties, which should enhance subsurface recharge and therefore baseflow as long as ET losses remain comparable (Muñoz-Villers et al. 2015). However, more work is needed to assess the hydrologic impacts of unmanaged mature pine plantations because they will likely have higher ET relative to managed stands (cf. Scott and Prinsloo 2008, Ghimire et al. 2014). Although catchment-scale data are not available for our site, the impacts of P. patula plantations on streamflow dynamics will be determined largely by whether or not increased water uptake by the trees is outweighed by positive impacts on increasing soil water infiltration and groundwater recharge (Bruijnzeel 2004, Ilstedt et al. 2007).

While water yield and flow regulation are the most common highpriority PHS goals, forest protection may enhance other ecosystem services, including carbon storage and climate change mitigation, biodiversity habitat, soil stabilization, and water filtration and quality (Martínez et al. 2009). Placing greater emphasis on the water quality benefits of forest conservation may be especially advantageous for PHS due to the typically faster response time (e.g., a few years for water quality compared to several decades for water yield due to the slow recovery of soils) (Meals et al. 2010), and secondly, by providing a rationale for other government agencies (e.g., the public health sector) to contribute directly to payments (Manson et al. 2013, Mokondoko et al. 2016). In the modeling study by Quintero et al. (2009), the PHS program was predicted to prevent a projected tripling of downstream sedimentation had those same lands under PHS enrollment been converted to agriculture, such that the estimated societal benefit from sediment reduction was greater than from increased dry-season flow. Mokondoko et al. (2016), working in 10 catchments in the area of the Veracruz study, showed a significant positive relationship between forest cover within 100 $\mathrm{m}$ of streams, water quality (as measured by $E$. coli counts), and public health in neighboring communities (incidence of cholera and other gastrointestinal diseases reported in public health records). Estimating the mitigation and defensive costs associated with contaminated water, their study generated a conservative estimate of the value of cloud forest cover (US\$90 $\mathrm{ha}^{-1} \mathrm{yr}^{-1}$ ), on par with current levels of PHS in Mexico. Thus, targeting the protection of riparian buffer zones as part of PHS programs could have large benefits in terms of enhancing water quality (Gove et al. 2001, Silva and Williams 2001).

\section{Is Mexico's Payments for Hydrologic Services program effective} at targeting hydrologic recharge zones within watersheds?

In addition to understanding the implications of land use change for water yield at the stand and catchment levels, a critical issue to be addressed at larger watershed scales is the location of recharge zones that contribute to sustained downstream baseflows. Since recharge zones are not necessarily correlated with vegetation type, site-specific evaluation and identification of recharge zones can provide valuable information for targeting and improving the impact of PHS programs. For instance, a study by 
Peñuela-Arévalo and Carrillo-Rivera (2013) assessed hydrologic discharge and recharge areas within Mexico City and surrounding states where the PHS program has operated since its initiation in 2003. They found that most groundwater recharge occurs at altitudes higher than $3300 \mathrm{~m}$, whereas most PHS-enrolled lands occurred below this altitude. Caballero et al. (2013) present results from a semidistributed water balance model that indicated that a cloud forest-dominated watershed had greater groundwater recharge than catchments without cloud forest, which resulted in a four-fold greater stream discharge from the cloud forestdominated watershed. In the case of the Los Gavilanes catchment within our Veracruz study, we estimated that the mean stream water residence times across different catchment areas ranged between 1.2 and 2.7 years, which suggests the presence of deep and presumably long subsurface flow paths that contribute to sustain baseflows, particularly during dry periods (Muñoz-Villers et al. 2016). Although these findings suggest that the upland areas -which coincide with pine-oak and cloud forests and highest rainfall totals - are the most important for groundwater recharge and downstream discharge, this study did not spatially identify recharge zones or evaluate linkages between PHS payments and recharge zones.

To explore further the spatial relationship between groundwater recharge and PHS payments at our Veracruz study site, we conducted a new analysis that identified and mapped areas of net water recharge (i.e., water yield) as the difference between mean annual $\mathrm{P}$ and ET (ignoring any small inputs via CWI), and then compared the resulting map with areas in the Pixquiac and Gavilanes watersheds that are receiving PHS. Comparisons were performed for all areas that received PHS payments during the period 2003-2011, and separately for the national (2007-2011) and matching (2008-2011) programs. Mean annual rainfall data from four weather stations (located at elevations of 1210, 1525, 2100 , and $2410 \mathrm{~m}$ ) in and around these watersheds were combined with climate data from Mexico's National Meteorological Network ( $>20$ years of data; ERIC III, CONAGUA) to describe the relationship between elevation and rainfall, using a polynomial regression model $\left(r^{2}=0.91\right)$. The resulting equation was combined with a digital elevation model (20-m intervals) to generate a raster map of rainfall as a function of altitude. A similar approach was followed for deriving a map of the Food and Agriculture Organization reference ET (ET $)$ (Allen et al. 1998) using climatic values from the three weather stations located within the study catchments to generate a second-degree polynomial regression $\left(r^{2}=0.75\right)$ that described $\mathrm{ET}_{0}$ as a function of altitude (Muñoz-Villers et al. 2012, 2015, Holwerda et al. 2013). A land use and land cover map generated from SPOT satellite images from 2008 and 2010 (20-m pixels; 840 training samples; kappa $=0.84$ ) was then used to map actual ET values by multiplying $\mathrm{ET}_{0}$ values by experimentally determined $\mathrm{ET} / \mathrm{ET}_{0}$ ratios for mature and secondary cloud forest, pastures, sugarcane, mature and young pine forests, and shade coffee (Holwerda et al. 2013, Muñoz-Villers et al. 2015). Other land uses such as urban zones, roads, and water bodies were assumed not to differ from $\mathrm{ET}_{0}$ and were assigned a value of 1 . To determine areas of net water recharge in our study watersheds, actual ET values from the map were subtracted from the mean annual rainfall. Levels of net water recharge were then divided into four equally distributed categories (low, medium, high, and very high) and were overlapped with maps of PHS.
The results of this analysis indicated that areas of high to very high net water recharge generally occurred in the middle and upper zones of the Los Gavilanes and Pixquiac watersheds (Fig. $1)$, while PHS coverage was greater in the former (65\% versus $44 \%$, respectively). The proportion of cloud forest located in these areas of high hydrologic water recharge showed a similar trend: $57 \%$ and $46 \%$ in the Gavilanes and Pixquiac watersheds, respectively. For the Gavilanes, the coverage of total PHS payments (2003-2011) or payments from only the matching program (2008-2011) was not significantly different from the observed distribution of net water recharge priorities; however, the national PHS program appeared to do much worse in covering high water recharge zones (Chi-square test, $P<0.001$ ) (Fig. 2a). For the Pixquiac, total and matching PHS payments covered significantly more areas of medium importance for net water recharge than would be expected from the observed distribution of recharge areas in the watershed (Chi-square test, $P<0.001$ ) (Fig. 2b). In contrast, payments made by the national PHS program covered significantly more high-priority water recharge areas in this watershed than expected from observed distributions (Chi-square test, $P<0.001$ ) (Fig. 2b).

Fig. 2. Comparison of the proportion of zones with different levels of net recharge within the Gavilanes (a) and Pixquiac (b) watersheds versus the coverage of land parcels receiving federal, local, or all types of payments for hydrologic services (PHS) during the period 2003-2011.

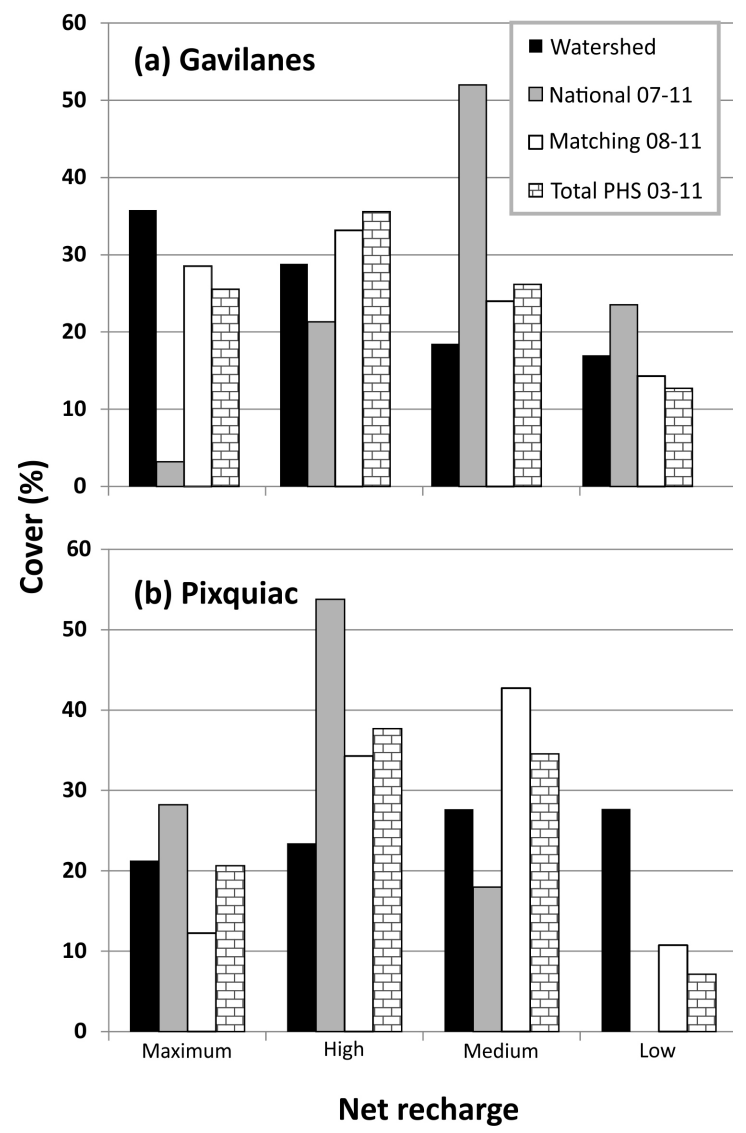


Combined, these findings suggest that over the 9-year study period, the effectiveness of PHS payments in covering highpriority water recharge zones has been inconsistent. Comparing across the two watersheds, there was greater overlap between payments and water recharge zones for the Pixquiac; however, the percentage of cloud forest areas that received PHS that were located in high water recharge zones was greater in Los Gavilanes. Comparing PHS programs, the national program performed better in the Pixquiac, while the matching program favored areas of medium importance or none at all. Given the small sample size in terms of the number of years and study watersheds, it is not possible to draw conclusive inferences about the underlying factors that contributed to these trends. However, the overall poorer performance of PHS payments in the Gavilanes versus Pixquiac watershed may reflect the varying degrees to which local program operators used scientific studies to refine payment distribution. Although there was a study that attempted to identify hydrological priority zones in the Gavilanes early in the implementation of the PHS program (García-Coll et al. 2004), this information was not used by program operators to refine payments. In contrast, program operators and local community groups in the Pixquiac identified priority areas for PHS early in the development of the program using a variety of factors, including water recharge, vulnerability, deforestation risk, and socioeconomic conditions (Fuentes-Pantay 2008, Paré and Geréz 2012). The fact that this program has not focused exclusively on hydrological services but also included societal priorities related to social equity and economic opportunities (Fuentes-Pangtay 2008) may also partly explain why areas of medium but not high net water recharge have received significantly more payments to date.

\section{Is Mexico's Payments for Hydrologic Services program successful at targeting areas of greatest deforestation risk for PHS enrollment?}

Given the assumption that increased forest cover will enhance hydrologic services, decision-makers in Mexico have sought to target areas for PHS that have the greatest risk of deforestation (used as a surrogate for opportunity cost) to increase program additionality (e.g., Muñoz-Piña et al. 2008, Alix-Garcia et al. 2014). To assess the success of such targeting in the Veracruz watersheds, we first determined the most important variables in predicting forest cover loss, and then compared the results with the distribution of actual PHS payments. Land cover data for the Pixquiac and Gavilanes catchments that spanned 13 years (19902003) (Muñoz-Villers and López-Blanco 2008) were combined to create a new map with two categories, "forest cover" and "other," to maximize model accuracy (Hall et al. 1995). The resulting raster layer (30-m pixels) was assigned values of 0 (no change), 1 (change), and "no data" (areas not forested in 1990). Two hundred pixels were then randomly selected using a minimum distance between points of 0.005 decimal degrees (approx. $500 \mathrm{~m}$ ) to reduce problems of spatial autocorrelation (Verburg et al. 2002). Values of these pixels were used as the dependent variable in stepwise logistic regression (SLR) (SAS Institute 1990) analysis to determine the relative importance of 13 different variables in explaining deforestation trends, including elevation $(\mathrm{m})$; slope $\left(^{\circ}\right)$; soil fertility (range 1-4 with 0.5 increments); mean annual precipitation and dry-season rainfall $(\mathrm{mm})$; distance to paved roads, pastures, and/or agricultural fields $(\mathrm{m})$; road density (mean value in a 2-km radius); distance to forest edge ( $\mathrm{m})$; percent forest cover in 1990 (within a 150-m radius); population density $\left(\# \mathrm{~km}^{-2}\right)$; and a unit-less national marginalization index based on standardized measures of education, household services, and income (range 0-100) (CONAPO 2002). Because the resulting ratio between pixels with change ( 47 pixels) versus no change (153 pixels) was not too skewed, the risk of generating biased probability estimates was deemed minimal (King and Zeng 2001). Under the assumption that land use change dynamics in the recent past (1990-2003) were likely to continue in the near future (Wilson et al. 2005), we used the SLR model results to identify remnant tracts of forest most at risk (i.e., having the highest predicted probability of transformation, Prob) where:

$$
\operatorname{Prob}=\mathrm{e}^{\operatorname{logit}(\mathrm{p})} /\left(1+\mathrm{e}^{\operatorname{logit}(\mathrm{p})}\right)
$$

Results indicated that the only variable that was significantly associated with forest conversion in the SLR model was the percentage of forest cover in 1990 (factor $\mathrm{X}$ in the model, Equation 2) (Table 1).

$$
\operatorname{logit}(\mathrm{p})=2.720+-4.980 * \mathrm{X}
$$

In this model, increased forest conversion was negatively associated with the percentage of adjacent area occupied by forest cover. A nonsignificant Hosmer and Lemeshow test $\left(X^{2}=3.970\right.$, d.f. $=8, p=0.860$ ) indicated good consistency between expected and observed event rates; however, the predictive power of the model was fairly low (Nagelkerke $R^{2}=0.177$ ), which suggests the need for additional finer scale studies in these watersheds to derive more robust explanatory variables. Overall, this model predicted no change $(0 ; 95.4 \%$ correct $)$ much better than change $(1 ; 19.1 \%)$. Model results were used to generate a map that identified tracts of forest with the highest risk of conversion in 2003, and then they were overlapped with those tracts that received PHS from the national and local programs during the period 2003-2011 (Fig. 3). While both the Pixquiac and Gavilanes areas exhibited very similar levels of forest cover (61\% versus $64 \%$ ), deforestation risk was predicted to be somewhat higher in the Pixquiac than in the Gavilanes ( $47 \%$ and $35 \%$ of the total forest area was classified as being either at high risk or very high risk, respectively) (Fig. $4 \mathrm{~b}, \mathrm{a})$. In contrast, when considering only cloud forest, $15 \%$ and $22 \%$ were classified as being either at high risk or very high risk of becoming deforested in the Pixquiac and Gavilanes areas, respectively (Fig. 4d, c).

Overlapping PHS payments with total forest cover during the period 2003-2011 (Fig. 3) revealed that payments covered a much greater proportion of the watershed in the Gavilanes (41\%) than in the Pixquiac (22\%). Payments in the Gavilanes mirrored the distribution of deforestation risk (Fig. 4a), while in the Pixquiac watershed, there was a trend of more payments than expected in low risk areas and fewer payments than expected in very high risk areas (Fig. 4b), particularly in the case of the matching program (Chi-square test, $P=0.044$ ). Neither watershed showed disproportionally more PHS in areas of highest deforestation risk, which is a basic criterion for achieving additionality and insuring program effectiveness. A similar pattern was observed when analyzing cloud forest cover separately. Both the total PHS and the matching program largely mirrored deforestation risk in the Gavilanes, whereas the national program made more payments 
Table 1. Results of a stepwise logistic regression analysis performed using 12 independent variables to explain changes $(0=$ no change, $1=$ conversion to other land use) in forest cover in the Pixquiac and Gavilanes watersheds during the period 1990-2003. See the text for a description of each variable.

\begin{tabular}{lcccccc}
\hline \hline Variable & B & SE & Wald Chi-square & df & Significance & Exp(B) \\
\hline Constant & 2.720 & 0.817 & 11.097 & 1 & 0.0001 & 15.187 \\
Percent forest in & -4.980 & 1.053 & 22.389 & 1 & 0.001 & 0.007 \\
1990 & & & & & & \\
\hline
\end{tabular}

Fig. 3. Map of risk of deforestation (divided into quintiles) of existing forest cover in 2003 generated via logistic regression analysis, and areas receiving payments for hydrologic services (PHS) from federal (diagonal line shading) or local (grey) matching programs in the Pixquiac and Gavilanes watersheds during the period 2003-2011. Probability ranges per risk category were $0.0945-0.1043$ (very low), $0.1043-0.1438$ (low), $0.1438-0.2193$ (medium), 0.2193-0.3868 (high), and 0.38680.9321 (very high).

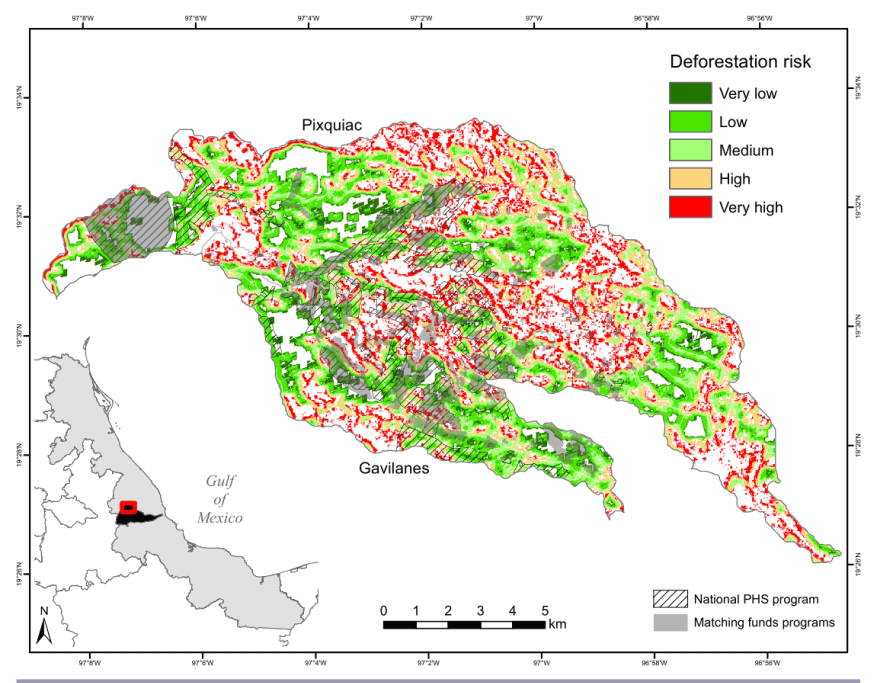

than expected in areas of medium risk (Chi-square test, $P=$ 0.0011) (Fig. 4c). Both payment types mirrored patterns of deforestation risk for cloud forest in the Pixquiac (Fig. 4d). Together, these findings are consistent with analyses conducted nationally (Alix-Garcia et al. 2014) and suggest that the current system for targeting PHS payments is not operating at maximum effectiveness; however, whether this is a result of patterns of landowner participation or motivation, the form of the payment, or some other factor(s), cannot be discerned from this information alone and is explored in greater detail in the following section.

Does Mexico's Payments for Hydrologic Services program produce social impacts that reduce the program's effectiveness? How PHS programs impact program participants may be critical for determining long-term success in achieving desired policy outcomes (Vatn 2010), including both intended and unintended impacts (Porras et al. 2008, Alix-Garcia et al. 2014, Hejnowicz et al. 2014). Understanding these impacts is important because of their potential to undermine PHS program goals of forest
Fig. 4. Comparison of the proportion of predicted deforestation risk within the Gavilanes (a) and Pixquiac (b) watersheds versus the coverage of land parcels receiving federal and local payments for hydrologic services (PHS) during the period 2003-2011; (a) and (b) include all forested areas; (c) and (d) include only cloud forest areas.
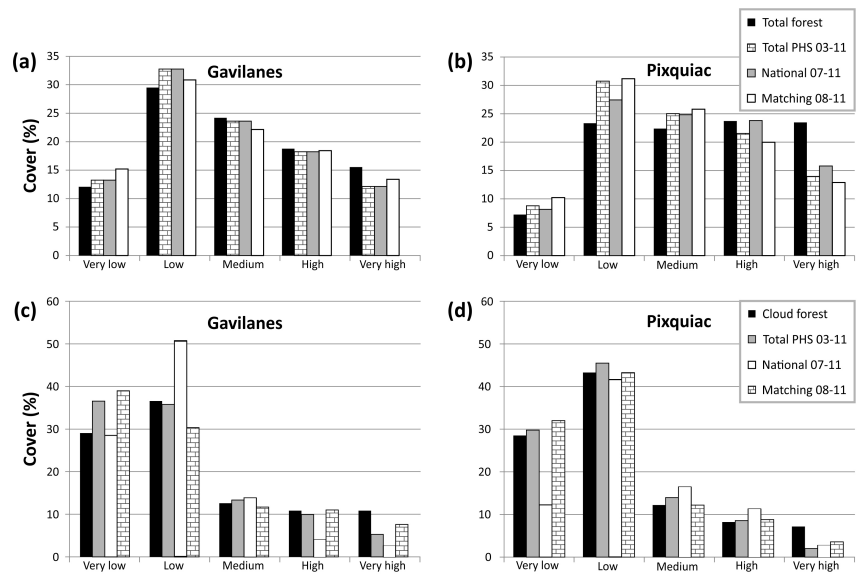

Deforestation risk

conservation and water protection (Van Noordwijk et al. 2012, Hejnowicz et al. 2014). The PHS literature highlights the importance of designing PHS programs with consideration of social impacts and the implications for long-term program efficacy (Landell-Mills and Porras 2002, Porras et al. 2008, Engel 2015). For example, PHS programs have been shown to modify local perceptions of forest value (Kosoy and Corbera 2010, Vatn 2010, Muradian et al. 2013), improve cooperation among upstream and downstream communities (Kosoy et al. 2007), and exacerbate tensions over land tenure (Robertson and Wunder 2005). The PHS literature also identifies specific components related to PHS program design that can influence program efficacy, including enrollment criteria (Wünscher et al. 2008), the payment amount (Butler et al. 2009), and monitoring programs (Engel et al. 2008). What remains less understood is how different PHS program designs can produce social impacts on participants (both intended and unintended), and how such impacts influence the efficacy of PHS programs.

Examples of relevant social impacts produced by PHS programs that may influence their effectiveness include the generation of undesirable behaviors and issues related to conflict and social cohesion (Pagiola et al. 2005, Porras et al. 2008). Thus, the goal 
of this study was to identify social impacts produced by the PHS programs in Veracruz that may influence long-term program efficacy. Specifically, we conducted field surveys of PHS participants enrolled in the municipality of Coatepec's PHS program, FIDECOAGUA, which operates as a matching funds program. The field surveys were conducted in 2009 and included 14 PHS participants (or $40 \%$ of total program participants) and 19 informed nonparticipants living in the Coatepec community. Interviews were conducted in the field by a trained field assistant over a period of one week. The focus of this field research was directed at observed social impacts from PHS programs in Veracruz that have been shown in the literature to influence PHS program efficacy, including knowledge generation among program participants (Echavarría et al. 2004, Lopa et al. 2012), unintended social impacts (Jack et al. 2008), and motivations for participant enrollment (Martin Persson and Alpizar 2013).

\section{Knowledge generation}

Previous research has shown that PHS programs can influence participant knowledge through a number of pathways, including by the degree to which participants understand program rules and objectives (Newton et al. 2012) and via alterations in personal perceptions and ethics related to the value of forest ecosystems (Kosoy and Corbera 2010, Vatn 2010, Muradian et al. 2013). In Veracruz, we identified several ways by which PHS programs may influence the knowledge of program participants, including through awareness of program rules and goals, and regional hydrological processes.

Several PHS studies in Veracruz suggest a high risk for participant noncompliance with land use requirements due to their poor knowledge of PHS regulations, which is likely to have an impact on program efficacy. In Scullion et al.'s (2011) study, $46 \%$ of those interviewed disagreed that participants' knowledge of PHS regulations was satisfactory, while 26\% agreed, and 28\% stated they did not know. In contrast, PHS participants in Veracruz were viewed as having a satisfactory understanding of the program's objectives by $48 \%$ of respondents, with $16 \%$ disagreeing, and $36 \%$ being unsure. A similar study in the adjacent Pixquiac watershed found that accurate knowledge about the PHS policies and objectives is not universal among local participants, as $62 \%$ of participants interviewed could not name the program they received payments from, and $75 \%$ said they did not believe there was any particular reason their property was eligible to receive PHS payments (Fuentes-Pangtay 2008). However, the same study also found that $65 \%$ of respondents accurately stated a primary goal of the PHS programs is to conserve water (Fuentes-Pangtay 2008). While few studies have explored how PHS programs influence participants' awareness of program regulations and goals, one study found similar results to those in Veracruz, with participants also having limited knowledge of at least one key aspect of the PHS program, in this case, the length of the contract term (Fisher 2012).

In contrast to inadequate levels of knowledge about program rules and goals, available evidence indicates that the PHS programs in Veracruz have had a positive influence on participants' environmental knowledge, which may provide an increased incentive for participants to adhere to program regulations. In the FIDECOAGUA study, $62 \%$ of the interviewees believed the PHS programs had increased environmental awareness of forest-water linkages. In these same interviews, $83 \%$ agreed that local forest loss leads to lower dry-season flow, and $70 \%$ agreed that forest loss in the region over the last 30 years had changed the local climate. These majority responses align with scientific understanding of hydrological dynamics in the region, although this study could not determine to what extent participation in, or knowledge from, PHS programs per se contributed to this understanding or whether this understanding extends to include the diverse hydrologic services provided by forests. Further research is needed, but the accurate environmental knowledge among sampled program participants may be partly explained by the educational outreach undertaken by local PHS programs, with one regional study finding that $65 \%$ of PHS participants reported having received environmental education from local PHS programs (Fuentes-Pangtay 2008). This case indicates the value of environmental outreach by PHS programs may be high, which is also highlighted by majorities of PHS participants in several PHS programs in Latin America having an inaccurate understanding of forest-water connections (Kosoy et al. 2007).

Motivations for Payments for Hydrologic Services enrollment The purpose of this section is to explain why some PHS participants enroll in programs when doing so has higher opportunity costs than the cash payment covers, and how participants "self-selecting" into PHS programs can result in reduced program efficacy. Highlighting the reasons why participants enroll in PHS programs besides financial incentives may also identify strategies to improve the design of PHS programs. A number of PHS studies have reported that payments received by participants are often below opportunity costs of alternative land use practices (Kosoy et al. 2007, Muñoz-Piña et al. 2008, Sommerville et al. 2010, Van Hecken and Bastiaensen 2010). This finding is important because it highlights how PHS program participation is influenced by a variety of factors, including economic considerations (Pham et al. 2009), social norms (Chen et al. 2009, Newton et al. 2012), and personal preferences (Kosoy et al. 2008, Fisher 2012). Thus, whether an individual will enroll (Wunder 2006) or not re-enroll (Hope et al. 2005 ) in a PHS program may depend on a combination of socioenvironmental factors, often in addition to the financial incentive of payments.

In the study area of Veracruz, we found that some PHS enrollment behavior also appears to be driven not just by payment value but also by a suite of social and environmental factors. For example, one study found that only $48 \%$ of program participants reported their initial motivation to enroll was due to the financial value of the PHS payment, with the other participants indicating they enrolled due to personal interest in conserving forests and reducing deforestation (González and Maritza 2014). Preferences for forest conservation were also reported to influence enrollment behavior among some PHS participants enrolled in the FIDECOAGUA program (Scullion et al. 2011). Another nonfinancial incentive of the Veracruz PHS programs reported in the FIDECOAGUA study was the program participants' perception that program enrollment is a way to access other government programs, which has also been documented elsewhere (Van Noordwijk et al. 2012).

A second factor that appears to influence PHS enrollment patterns and program efficacy in Veracruz is the existence of high 
economic returns for alternative land uses compared to relatively low returns for PHS payments (Scullion et al. 2011). This finding indicates that some PHS participants in Veracruz enrolled because they have low opportunity costs and/or their enrollment motivations extend beyond the incentives provided by financial payments. For example, in 2008, farmers with suitable land and capital in Veracruz could earn an average US\$2088 $\mathrm{ha}^{-1} \mathrm{yr}^{-1}$ by planting sugarcane, and farmers could earn US $\$ 384 \mathrm{ha}^{-1} \mathrm{yr}^{-1}$ by planting coffee (Scullion et al 2011). At the same time, PHS payments for priority forest ecosystems in the region did not exceed US\$1110 ha $\mathrm{hr}^{-1}$ (CONAFOR 2012). As noted by AlixGarcia et al. (2014), when land use alternatives available to forest owners in Mexico strongly favor forest conversion, current PHS payments may not provide sufficient incentives for conservation. The results from our deforestation risk analysis support this possibility, as high deforestation risk areas were less likely to be covered by PHS payments than areas with low deforestation risk (Fig. 4), but whether this was due to landowners' unwillingness to accept relatively low PHS payments or to ineffective recruiting by the PHS program could not be discerned.

What is clear is that most PHS participants in Veracruz report that the payments they receive are "too low" (Scullion et al. 2011) or "insufficient" (González and Maritza 2014), or are viewed as a "tip" or recognition of those already convinced about the importance of sustainable management (Rodríguez Camargo 2015), yet they are actively enrolled in the programs. Popularity of PHS programs, despite concerns about low payments, can also be seen with Mexico's PHS program nationwide, as there are more applicants than the program can support, including in 2008, when only $21 \%$ of applicants were funded (Muñoz-Piña et al. 2008, 2011). Taken together, several PHS studies from Veracruz highlight how the financial incentive of the PHS payments per se was not the only factor motivating land users who enrolled. This finding is not unique to Veracruz, as other PHS studies in Latin America have shown that PHS participants receive payments that provide only a small proportion of their income (Kosoy et al. 2007). The apparent limited influence of payment amount across PHS programs highlights the importance of evaluating the reasons why participants decide to enroll, or "self-select," into a program because when their personal opportunity costs are relatively low, program additionality may decline since tangible impacts from the PHS policy on participants' land use behavior may be limited (Martin Persson and Alpizar 2013). Collectively, the evidence presented shows how a combination of social, environmental, and economic factors can influence the enrollment behavior of PHS participants, and why designing enrollment processes to reduce self-selection and increase the enrollment of vulnerable parcels can increase program efficacy (Wünscher et al. 2008, Martin Persson and Alpizar 2013).

These findings from our Veracruz study also provide evidence that PHS programs may be seen by some participants as not only a strict fee-for-service conservation program but also as one competitive option among many potential land use options that carry real and perceived costs and benefits (Sommerville et al. 2010). Additionally, some studies suggest that including greater local participation in program design or more flexible payment structures (e.g., supporting sustainable land use alternatives), features characteristic of Mexico's matching PHS program, may be more effective at promoting sustained changes in behavior
(Reed 2008, Petheram and Campbell 2010). However, our findings for Veracruz on the broad scale relationship between program type and deforestation risk across the two study watersheds do not suggest clear differences between the effectiveness of the two programs. This is in spite of considerable differences in these local matching programs. While the PHS program in the Pixquiac works more closely with local communities, is more creative with compensation mechanisms, and has made a concerted effort to use existing scientific information to improve payment targeting, program effectiveness versus the Gavilanes PHS program may be limited due to a weaker legal framework and constant budgetary constraints. More indepth and extensive (e.g., additional watersheds and soil types) analyses in conjunction with comprehensive surveys of participants and nonparticipants are needed to understand how the design of these programs influences participants' land use decisions and behaviors.

\section{Unintended social impacts}

This section is designed to highlight several unintended social impacts of the Veracruz PHS programs that are likely to influence long-term program efficacy, specifically perverse incentives, undesirable behaviors, and reduced trust and social cohesion. While many PHS programs have explicit social goals, such as poverty alleviation and job creation (Landell-Mills and Porras 2002, Porras et al. 2008), a variety of unintended social impacts have also been documented, including increased social cooperation and increased land tenure conflict (Porras et al. 2008). As discussed, one reason for the production of unintended impacts by PHS programs is their ability to alter existing socioeconomic incentives, such as through participant enrollment preferences. Another example from Veracruz that illustrates how unintended social outcomes may influence program efficacy is the case of an upper watershed community that effectively ransomed their high-elevation forests in demanding that forestry officials pay them PHS payments not to cut their forests (Diario de Xalapa, January 13, 2012). The potential for ransoming due to the presence of incentive-based policy instruments like PHS has been discussed elsewhere (Jack et al. 2008) but has remained poorly documented in the field. Another example in Veracruz of how PHS programs can unintentionally generate perverse social incentives is a situation whereby landowners cut down their forests in order to become eligible for government financed reforestation programs (T. Fuentes, personal observation); these lands later become eligible for PHS enrollment. A similar example also in Veracruz includes a PHS participant who enrolled to gain the financial capital needed to plant potatoes on the forest site after the contract term expired (Fuentes-Pangtay 2008). A final example of an undesirable social impact identified from PHS programs in Veracruz was the perception that the PHS programs reduced trust and cooperation among program participants and the government (Scullion et al. 2011). A decrease in community trust is important because it has been shown that a loss of trust can negatively influence the efficacy of a PHS program (Jack et al. 2008). Taken together, these findings show how unintended social outcomes from PHS programs may harm the long-term goals of forest and water protection. To avoid such outcomes, PHS programs require permanent monitoring, effective management, and rigorous participant enrollment processes that provide differentiated payments by forest value and vulnerability (Engel et al. 2008, Wünscher et al. 2008, Ezzine-de-Blas et al. 
2016). Questions raised by these examples and which require further research include the following: What types of unintended social impacts produced by PHS programs have the potential to undermine PHS program efficacy? How should PHS programs be designed to strengthen positive social outcomes and mitigate negative outcomes? And what is the durability of PHS payments in influencing long-term conservation behavior among participants, as program impacts on participants' behavior may be highly dynamic (Sommerville et al. 2010)?

In summary, this case study shows how the Veracruz PHS programs produce a variety of desirable and undesirable social impacts on participants that can influence program efficacy. An important conclusion we draw from this study is how the longterm efficacy of PHS programs in Veracruz is likely to be linked to participant enrollment dynamics and the education of program participants. Notably, our Veracruz study showed a belief by PHS participants that the program did enhance their knowledge of forest-water connections, although the link between participants' perceptions and motivations, and their actual decisions and behaviors, remains unclear. Moreover, the PHS literature overall suggests that greater emphasis on communicating the broader range of hydrologic services provided by forests is needed rather than the simplistic (and in many cases unfounded) message that more forests leads to more water at all times of the year (Manson et al. 2013).

\section{CONCLUSIONS}

Currently, Mexico's Payments for Hydrologic Services program prioritizes protection of cloud forests over other forest types through higher payments under the rationale that cloud forests make greater contributions to water yield. However, our ecohydrological research suggests a more complex relationship between forests and hydrologic services, with cloud forests having lower annual water yield than pasture but playing a critical role in other hydrologic services, such as flow regulation (e.g., reducing peak flows and maintaining dry-season baseflow), groundwater recharge, and water quality. Further, these functions may not be associated with (cloud) forest but may be more strongly related to topographic, edaphic, and geologic characteristics of the watershed that promote infiltration and significant groundwater recharge. These findings suggest some level of disconnect between how Mexico's PHS programs priorities were initially conceived and communicated, and the actual hydrologic services provided. In particular, other forest types, such as regenerating broad-leaved forests or pine plantations, or specific watershed locations, such as recharge zones, may have hydrologic functions on par with cloud forests. More research is needed to improve knowledge of the location of net water recharge zones with high rainfall in relation to land cover type and geology, and to develop policy tools for enhancing the capacity of PHS to target areas with maximum hydrologic services.

Interestingly, despite some discordance between stated program objectives and actual hydrologic benefits from cloud forests, residents within watersheds participating in the PHS program perceived that the program had contributed to enhanced awareness of forest-water relationships. However, additional research is needed to tease apart the more complex aspects of people's understanding, especially regarding cloud forests versus other forest types, dry-season flow versus total water yield, and hydrologic regulation and water quality issues. Another important finding was the apparent lack of a strong connection between the payment (incentive) and the motivation for enrollment and participants' behaviors related to forest and water protection. This disconnection was also reflected in the poor overlap between parcels receiving PHS payments and risk of deforestation, which suggests that either program recruiting was inadequate or ineffective, or that landowners in high deforestation risk areas were less motivated to participate, possibly due to a mismatch between payment amount and opportunity costs. A consequence of this disconnection may be lower program efficiency (e.g., payments being made to areas that would likely have been conserved even without payments; i.e., low additionality) (Sierra and Russman 2006), as well as reduced impact on targeted hydrologic services owing to the greater loss of forest cover in high deforestation risk areas. Further research is needed to better understand the underlying motivations influencing PHS participation as a basis for designing PHS programs in ways that better align with people's decision-making processes in relation to priority watershed areas.

One promising means of minimizing the potential for confusion or miscommunication about the effectiveness of the PHS program in achieving its objectives or in motivating participation by landowners is to include multiple ecosystem services provided by forests (e.g., biodiversity, carbon sequestration, recreational value, as well as both water supply and water quality) (Martínez et al. 2009, Townsend et al. 2012, Manson et al. 2013). Mexico's PHS program appears to be already moving in this direction, as it currently includes the possibility of supporting any ecosystem service (with the exception of carbon sequestration, which is covered under a new REDD+ program), even though to date most of the landowners enrolled continue to receive payments for hydrologic services (Muñoz-Piña et al. 2011). An additional benefit of expanding the PHS program to include multiple services is the potential for attracting a broader range of donors, thereby potentially allowing for higher payments that more closely match opportunity costs in high deforestation risk areas (Mokondoko et al. 2016). Lastly, PHS programs would greatly benefit from incorporating mechanisms for targeting enrollment and assigning payment amounts that integrate both socioeconomic and ecohydrologic criteria, including opportunity costs, hydrologic importance, deforestation risk, and multiple ecosystem services.

Overall, PHS programs offer a powerful approach for explicitly linking watershed service "producers" and "consumers" through voluntary compensation mechanisms that may promote greater forest conservation and diverse ecosystem services compared to previous approaches that rely heavily on regulation and enforcement. However, as demonstrated by our synthesis of Mexico's Veracruz case study, the success of these programs will ultimately depend on improved understanding of the complex dynamics between PHS policies and the responses of individual stakeholders and whole societies. This will require greater interdisciplinary collaboration to ensure effective monitoring, analysis, and integration of socioeconomic and biophysical information and decision-making and policy design processes.

Responses to this article can be read online at: http://www.ecologyandsociety.org/issues/responses. php/9144 


\section{Acknowledgments:}

The authors would like to acknowledge the National Science Foundation (awards NSF-CNH \#1313804 and NSF-DEB \#1156143) for funding in support of the research conducted for this synthesis.

\section{LITERATURE CITED}

Alila, Y., R. Hudson, P. K. Kuras, M. Schnorbus, and K. Rasouli. 2010. Reply to comment by Jack Lewis et al. on "Forests and floods: a new paradigm sheds light on age-old controversies". Water Resources Research 46:W05802. http://dx.doi. org/10.1029/2009WR009028

Alila, Y., P. K. Kuras, M. Schnorbus, and R. Hudson. 2009. Forests and floods: a new paradigm sheds light on age-old controversies. Water Resources Research 45(8):W08416. http://dx. doi.org/10.1029/2008wr007207

Alix-Garcia, J., G. Aronson, V. Radeloff, C. Ramirez-Reyes, E. Shapiro, K. Sims, and P. Yañez-Pagans. 2014. Environmental and socioeconomic impacts of Mexico's Payments for Ecosystem Services Program. 3ie Grantee Final Report. International Initiative for Impact Evaluation, New Delhi, India.

Alix-Garcia, J., A. Janvry, E. Sadoulet, J. M. Torres, J. B. Varela, and M. Z. Ramos. 2005. An assessment of Mexico's payment for environmental services program. Prepared for the Food and Agriculture Organization of the United Nations by UC Berkeley and the Centre for Research and Teaching of Economics, Mexico.

Allen, R. G., L. S. Pereira, D. Raes, and M. Smith. 1998. Crop evapotranspiration - guidelines for computing crop water requirements. FAO Irrigation and Drainage Paper 56. Food and Agriculture Organization of the United Nations, Rome, Italy.

Alvarado-Barrientos, M. S. 2013. Plant water use and canopy-fog interactions across a land use change trajectory of pasture to pine reforestation in a seasonally dry tropical montane cloud belt. Dissertation. University of New Hampshire, Durham, New Hampshire, USA.

Alvarado-Barrientos, M. S., F. Holwerda, H. Asbjornsen, T. E. Dawson, and L. A. Bruijnzeel. 2014. Suppression of transpiration due to cloud immersion in a seasonally dry Mexican weeping pine plantation. Agricultural and Forest Meteorology 186:12-25. http:// dx.doi.org/10.1016/j.agrformet.2013.11.002

Asbjornsen, H., A. S. Mayer, K. W. Jones, T. Selfa, L. Saenz, R. K. Kolka, and K. E. Halvorsen. 2015. Assessing impacts of payments for watershed services on sustainability in coupled human and natural systems. BioScience 65(6):579-591. doi: 10.1093/biosci/biv051 http://dx.doi.org/10.1093/biosci/biv051

Balmford, A., and W. Bond. 2005. Trends in the state of nature and their implications for human well-being. Ecology Letters 8 (11):1218-1234. http://dx.doi.org/10.1111/j.1461-0248.2005.00814. $\underline{\mathrm{X}}$

Bathurst, J. C., A. Iroumé, F. Cisneros, J. Fallas, R. Iturraspe, M. Gaviño Novillo, A. Urciuolo, B. de Bièvre, V. Guerrero Borges, C. Coello, P. Cisneros, J. Gayoso, M. Miranda, and M. Ramírez. 2011. Forest impact on floods due to extreme rainfall and snowmelt in four Latin American environments 1: field data analysis. Journal of Hydrology 400:281-291. http://dx.doi. org/10.1016/j.jhydrol.2010.11.044

Bender, M. A., T. R. Knutson, R. E. Tuleya, J. J. Sirutis, G. A. Vecchi, S. T. Garner, and I. M. Held. 2010. Modeled impact of anthropogenic warming on the frequency of intense Atlantic hurricanes. Science 327 (5964):454 458. http://dx.doi.org/10.1126/ science. 1180568

Birkel, C., C. Soulsby, and D. Tetzlaff. 2012. Modelling the impacts of land-cover change on streamflow dynamics of a tropical rainforest headwater catchment. Hydrological Sciences Journal 57(8):1543-1561. http://dx.doi.org/10.1080/02626667.2012.728707

Bradshaw, C. J. A., N. S. Sodhi, K. S.-H. Peh, and B. W. Brook. 2007. Global evidence that deforestation amplifies flood risk and severity in the developing world. Global Change Biology 13 (11):2379-2395. http://dx.doi.org/10.1111/j.1365-2486.2007.01446. $\underline{\mathrm{X}}$

Brauman, K. A., G. C. Daily, T. K. Duarte, and H. A. Mooney. 2007. The nature and value of ecosystem services: an overview highlighting hydrologic services. Annual Review of Environmental and Resources 32:67-98. http://dx.doi.org/10.1146/annurev. energy.32.031306.102758

Bremer, L. L., K. A. Farley, and D. Lopez-Carr. 2014. What factors influence participation in payment for ecosystem services programs? An evaluation of Ecuador's SocioParamo program. Land Use Policy 36:122-133. http://dx.doi.org/10.1016/j. landusepol.2013.08.002

Brouwer, R., A. Tesfaye, and P. Pauw. 2011. Meta-analysis of institutional-economic factors explaining the environmental performance of payments for watershed services. Environmental Conservation 38(4):380-392. http://dx.doi.org/10.1017/ $\underline{\mathrm{s} 0376892911000543}$

Brown, M. B., I. de la Roca, A. Vallejo, G. Ford, J. Casey, et al. 1996. A valuation analysis of the role of cloud forests in watershed protection. Sierra de las Minas Biosphere Reserve, Guatemala and Cusuco N.P. Honduras. RARE Center for Tropical Conservation, Philadelphia, Pennsylvania, USA.

Bruijnzeel, L. A. 2004. Hydrological functions of tropical forests: not seeing the soil for the trees? Agriculture Ecosystems \& Environment 104:185-228. http://dx.doi.org/10.1016/j.agee.2004.01.015

Bruijnzeel, L. A., R. Burkard, A. Carvajal, A., Frumau, L. Köhler, M. Mulligan, J. Schellekens, S. Schmid, and C. Tobón. 2006. Hydrological impacts of converting tropical montane cloud forest to pasture, with initial reference to northern Costa Rica. DFID Project Report.

Bruijnzeel, L. A., M. Kappelle, M. Mulligan, and F. N. Scatena. 2010. Tropical montane cloud forests: state of knowledge and sustainability perspectives in a changing world. Pages 691-700 in L. A. Bruijnzeel, F. N. Scatena, and L. S. Hamilton, editors. Tropical montane cloud forests: science for conservation and management. Cambridge University Press, Cambridge. http://dx. doi.org/10.1017/cbo9780511778384.074

Bruijnzeel, L. A., M. Mulligan, and F. N. Scatena. 2011. Hydrometeorology of tropical montane cloud forests: emerging 
patterns. Hydrological Processes 25(3):465-498. http://dx.doi. org/10.1002/hyp.7974

Bubb, P., I. May, L. Miles, and J. Sayer. 2004. Cloud forest agenda. UNEP-WCMC Biodiversity Series No. 20.

Butler, R. A., L. P, Koh, and J. Ghazoul. 2009. REDD in the red: palm oil could undermine carbon payment schemes. Conservation Letters 2(2):67-73. http://dx.doi.org/10.1111/j.1755-263X.2009.00047. $\underline{x}$

Buytaert, W., V. Iñiguez, and B. De Bièvre. 2007. The effects of afforestation and cultivation on water yield in the Andean páramo. Forest Ecology and Management 251:22-30. http://dx. doi.org/10.1016/j.foreco.2007.06.035

Caballero, L. A., Z. M. Easton, B. K. Richards, and T. S. Steenhuis. 2013. Evaluating the bio-hydrological impact of a cloud forest in Central America using a semi-distributed water balance model. Journal of Hydrology and Hydromechanics 61 (1):9-20. http://dx.doi.org/10.2478/jhh-2013-0003

Chen, X., F. Lupi, G. He, and J. Liu. 2009. Linking social norms to efficient conservation investment in payments for ecosystem services. Proceedings of the National Academy of Sciences of the United States of America 106:11812-11817. http://dx.doi. org/10.1073/pnas.0809980106

Cingolani, A. M., M. Poca, M. A. Giorgis, M. V. Vaieretti, D. E. Gurvich, J. I. Whitworth-Hulse, and D. Renison. 2015. Water provisioning services in a seasonally dry subtropical mountain: identifying priority landscapes for conservation. Journal of Hydrology 525:178-187. http://dx.doi.org/10.1016/j.jhydrol.2015.03.041

CONAFOR (Comisión Nacional Forestal, MX). 2012. Datos proporcionados por la Coordinación General de Producción y Productividad. Guadalajara, México. Comisión Nacional Forestal.

CONAPO. 2002. Índice de marginación a nivel localidad, 2000. Consejo Nacional de Población. México, D.F.

Daw, T. I. M., K. Brown, S. Rosendo, and R. Pomeroy. 2011. Applying the ecosystem services concept to poverty alleviation: the need to disaggregate human well-being. Environmental Conservation 38(04):370-379. http://dx.doi.org/10.1017/ $\underline{\mathrm{S} 0376892911000506}$

Diario de Xalapa. January 13, 2012. "Amenazan con dejar sin agua a Xalapa".

Dierick, D., and D. Hölscher. 2009. Species-specific tree water use characteristics in reforestation stands in the Philippines. Agricultural and Forest Meteorology 149:1317-1326. http://dx. doi.org/10.1016/j.agrformet.2009.03.003

Echavarría, M., J. Vogel, M. Albàn, and F. Meneses. 2004. The impacts of payments for watershed services in Ecuador. Emerging lessons from Pimampiro and Cuenca. Markets for Environmental Series Report No. 4. IIED, London, UK.

Ellis, E. A., J. A. Romero, I. U. Hernandez, C. A. Gallo, and J. L. Alanis. 2012. Geographical evaluation of areas susceptible to flooding in the Tuxpan River watershed, Veracruz, Mexico. Advances in Agricultural Research 16(1):7-28.
Engel, S. 2015. The devil in the detail: a practical guide on designing payments for environmental services. SSRN 2712376.

Engel, S., S. Pagiola, and S. Wunder. 2008. Designing payments for environmental services in theory and practice: an overview of the issues. Ecological Economics 65(4):663-674. http://dx.doi. org/10.1016/j.ecolecon.2008.03.011

Ezzine-de-Blas, D., S. Wunder, M. Ruiz-Pérez, and R. P. MorenoSanchez. 2016. Global patterns in the implementation of payments for environmental services. PloS one 11(3):e0149847. http://dx.doi.org/10.1371/journal.pone.0149847

Farley, K. A., E. G. Jobbágy, and R. B. Jackson. 2005. Effects of afforestation on water yield: a global synthesis with implications for policy. Global Change Biology 11:1565-1576. http://dx.doi. org/10.1111/j.1365-2486.2005.01011.x

Fisher, J. 2012. No pay, no care? A case study exploring motivations for participation in payments for ecosystem services in Uganda. Oryx 46(1):45-54. http://dx.doi.org/10.1017/ s0030605311001384

Fleischbein, K., W. Wilcke, R. Goller, J. Boy, C. Valarezo, W. Zech, and K. Knoblich. 2005. Rainfall interception in a lower montane forest in Ecuador: effects of canopy properties. Hydrological Processes 19:1355-1371. http://dx.doi.org/10.1002/hyp.5562

Fuentes-Pangtay, T. 2008. Análisis de los programas de pago o compensación por servicios ambientales en la Cuenca del Pixquiac: Fortalezas y debilidades en el contexto local. Report on behalf of Fondo Mexicano para la Conservación de la Naturaleza, AC (FMCN) y de la Agencia de los Estados Unidos de América para el Desarrollo Internacional (USAID), Coatepec, Mexico [in Spanish].

García-Coll, I., A. Martínez-Otero, A. Ramírez-Soto, A. NiñoCruz, A. J. Rivas, L. Domínguez-Barrada. 2004. Relación aguabosque: delimitación de zonas prioritarias para pago de servicios ambientales hidrológicos en la cuenca del río Gavilanes, Coatepec, Veracruz. Pages 99-115 in H. Cotler, editor. Manejo integral de cuencas en México: estudios y reflexiones para orientar la política ambiental INE/SEMARNAT, Mexico City, D.F., Mexico.

Ghimire, C. P., M. Bonell, L. A. Bruijnzeel, N. A. Coles, and M. W. Lubczynski. 2013. Reforesting severely degraded grassland in the Lesser Himalaya of Nepal: effects on soil hydraulic conductivity and overland flow production. Journal of Geophysical Research: Earth Surface 118:2528-2545. http://dx. doi.org/10.1002/2013jf002888

Ghimire, C. P., M. W. Lubczynski, L. A. Bruijnzeel, and D. Chavarro-Rincón. 2014. Transpiration, canopy conductance and decoupling coefficient of two contrasting forest types in the Lesser Himalaya of Central Nepal. Agricultural and Forest Meteorology 197:76-90. http://dx.doi.org/10.1016/j.agrformet.2014.05.012

Goldman-Benner, R. L., S. Benitez, T. Boucher, A. Calvache, G. Daily, P. Kareiva, T. Kroeger, and A. Ramos. 2012. Water funds and payments for ecosystem services: practice learns from theory and theory can learn from practice. Oryx 46(1):55-63. http://dx. doi.org/10.1017/s0030605311001050 
Goldstein, J. H., G. Caldarone, T. K. Duarte, D. Ennaanay, N. Hannahs, G. Mendoza, S. Polasky, S. Wolny, and G. C. Daily. 2012. Integrating ecosystem-service tradeoffs into land-use decisions. Proceedings of the National Academy of Sciences of the United States of America 109(19)7565-7570. http://dx.doi. org/10.1073/pnas.1201040109

González, R., and D. Maritza. 2014. Evaluación ambiental y socio-económica del programa de pago por servicios ambientales hidrológicos. FIDECOAGUA-CONAFOR, municipio de Coatepec, Veracruz, Mexico.

Gove, N. E., R. T. Edwards, and L. L. Conquest. 2001. Effects of scale on land use and water quality relationships: a longitudinal basin-wide perspective. Journal of American Water Resources Association 37(6):1721-1733. http://dx.doi.org/10.1111/j.1752-1688.2001. tb03672.x

Grieg-Gran, M., I. Porras, and S. Wunder. 2005. How can market mechanisms for forest environmental services help the poor? Preliminary lessons from Latin America. World Development 33 (9):1511-1527. http://dx.doi.org/10.1016/j.worlddev.2005.05.002

Guariguata, M. R., and P. Balvanera. 2009. Tropical forest service flows: improving our understanding of the biophysical dimension of ecosystem services. Forest Ecology and Management 258:18251829. http://dx.doi.org/10.1016/j.foreco.2009.06.025

Hall, C. A. S., H. Tian, Y. Qi, G. Pontius, and J. Cornell. 1995. Modelling spatial and temporal patterns of tropical land use change. Journal of Biogeography 22:753-757. http://dx.doi. org/10.2307/2845977

Hayes, T. M. 2012. Payment for ecosystem services, sustained behavioural change, and adaptive management: peasant perspectives in the Colombian Andes. Environmental Conservation 39(2):144-153. http://dx.doi.org/10.1017/ $\underline{\mathrm{s} 0376892912000045}$

Hejnowicz, A. P., D. G. Raffaelli, M. A. Rudd, and P. C. L. White. 2014. Evaluating the outcomes of payments for ecosystem services programmes using a capital asset framework. Ecosystem Services 9:83-97. http://dx.doi.org/10.1016/j.ecoser.2014.05.001

Holwerda, F. 2005. Water and energy budgets of rain forests along an elevation gradient under maritime tropical conditions. Dissertation. VU University Amsterdam, Amsterdam, The Netherlands.

Holwerda, F., L. A. Bruijnzeel, V. L. Barradas, and J. Cervantes. 2013. The water and energy exchanges of a shaded coffee plantation in the lower montane cloud forest zone of central Veracruz, Mexico. Agricultural and Forest Meteorology 173:1-13. http://dx.doi.org/10.1016/j.agrformet.2012.12.015

Holwerda, F., L. A. Bruijnzeel, L. E. Muñoz-Villers, M. Equihua, and H. Asbjornsen. 2010. Rainfall and cloud water interception in mature and secondary lower montane cloud forests of central Veracruz, Mexico. Journal of Hydrology 384:84-96. http://dx.doi. org/10.1016/j.jhydrol.2010.01.012

Holwerda, F., R. Burkard, W. Eugster, F. N. Scatena, A. G. C. A. Meesters, and L. A. Bruijnzeel. 2006. Estimating fog deposition at a Puerto Rican elfin cloud forest site: comparison of the water budget and eddy covariance methods. Hydrological Processes 20:2669-2692. http://dx.doi.org/10.1002/hyp.6065
Hope, R. A., I. T. Porras, and M. Miranda. 2005. Can payments for environmental services contribute to poverty reduction? A livelihoods analysis from Arenal, Costa Rica. International Institute for Environment and Development, London, UK.

Hornbeck, J. W., M. B. Adams, E. S. Corbett, E. S. Verry, and J. A. Lynch. 1993. Long-term impacts of forest treatments on water yield: a summary for northeastern USA. Journal of Hydrology 150:323-344. http://dx.doi.org/10.1016/0022-1694(93)90115-P

Huber, A., A. Iroumé, , and J. Bathurst. 2008. Effects of Pinus radiata plantations on water balance in Chile. Hydrological Processes 22:142-148. http://dx.doi.org/10.1002/hyp.6582

Ilstedt, U., A. Malmer, E. Verbeeten, and D. Murdiyarso. 2007. The effect of afforestation on water infiltration in the tropics: a systematic review and meta-analysis. Forest Ecology and Management 251:45-51. http://dx.doi.org/10.1016/j.foreco.2007.06.014

INEGI. 2011. Censo de Población y Vivienda, 2010 (Informe nacional y estatal). Instituto Nacional de Estadística, Geografía e Informática. http://www.beta.inegi.org.mx/proyectos/ccpv/2010/

Jack B. K., C. Kousky, and K. R. E. Sims. 2008. Designing payments for ecosystem services: lessons from previous experience with incentive-based mechanisms. Proceedings of the National Academy of Sciences of the United States of America 105(28):9465-9470. http://dx.doi.org/10.1073/pnas.0705503104

Janzen, D., and J. J. McDonnell. 2015. A stochastic approach to modeling and understanding hillslope runoff connectivity dynamics. Ecological Modelling 298:64-74. http://dx.doi. org/10.1016/j.ecolmodel.2014.06.024

Jarvis, A., and M. Mulligan. 2011. The climate of cloud forests. Hydrological Processes 25:327-343. http://dx.doi.org/10.1002/ hyp. 7847

Jenerette, G. D., W. A. Marussich, and J. P. Newell. 2006. Linking ecological footprints with ecosystem valuation in the provisioning of urban freshwater. Ecological Economics 59:38-47. http://dx. doi.org/10.1016/j.ecolecon.2005.09.023

Johnson, N., A. White, and D. Perrot-Maitre. 2001. Developing markets for water services from forests: issues and lessons for innovators. Forest Trends, Washington, D.C., USA.

Kaczan, D., B. M. Swallow, and W. L. Adamowicz. 2013. Designing a payments for ecosystem services (PES) program to reduce deforestation in Tanzania: an assessment of payment approaches. Ecological Economics 95:20-30. http://dx.doi. org/10.1016/j.ecolecon.2013.07.011

Kaimowitz, D. 2004. Forests and water: a policy perspective. Journal of Forest Research 9(4):289-291. http://dx.doi. org/10.1007/s10310-004-0112-0

King, G., and L. Zeng. 2001. Logistic regression in rare events data. Political Analysis 9:137-163. http://dx.doi.org/10.1093/ oxfordjournals.pan.a004868

Kosoy, N., and E. Corbera. 2010. Payments for ecosystem services as commodity fetishism. Ecological Economics 69(6):1228-1236. http://dx.doi.org/10.1016/j.ecolecon.2009.11.002

Kosoy, N., E. Corbera, and K. Brown. 2008. Participation in payments for ecosystem services: case studies from the Lacandon 
rainforest, Mexico. Geoforum 39(6)2073-2083. http://dx.doi. org/10.1016/j.geoforum.2008.08.007

Kosoy, N., M. Martinez-Tuna, R. Muradian, and J. MartinezAlier. 2007. Payments for environmental services in watersheds: insights from a comparative study of three cases in Central America. Ecological Economics 61(2):446-455. http://dx.doi. org/10.1016/j.ecolecon.2006.03.016

Landell-Mills, N. and I. T. Porras. 2002. Silver bullet or fools' gold? A global review of markets for forest environmental services and their impact on the poor. International Institute for Environment and Development, London, UK.

Lele, S. 2009. Watershed services of tropical forests: from hydrology to economic valuation to integrated analysis. Current Opinion in Environmental Sustainability 1:148-155. http://dx.doi. org/10.1016/j.cosust.2009.10.007

Lewis, J., L. M. Reid, and R. B. Thomas. 2010. Comment on "Forest and floods: A new paradigm sheds light on age-old controversies" by Younes Alila et al. Water Resources Research 46:W05801. http://dx.doi.org/10.1029/2009wr008766

Little, C., A. Lara, J. McPhee, and R. Urrutia. 2009. Revealing the impact of forest exotic plantations on water yield in large scale watersheds in south-central Chile. Journal of Hydrology 374:162170. http://dx.doi.org/10.1016/j.jhydrol.2009.06.011

Liu, J., S. Li, Z. Ouyang, C. Tam, and X. Chen. 2008. Ecological and socioeconomic effects of China's policies for ecosystem services. Proceedings of the National Academy of Sciences of the United States of America 105(28):9477-9482. http://dx.doi. org/10.1073/pnas.0706436105

Lopa, D., I. Mwanyoka, G. Jambiya, T. Massoud, P. Harrison, M. E. Jones, T. Blomley, B. Leimona, M. van Noordwijk, and N. D. Burgess. 2012. Towards operational payments for water ecosystem services in Tanzania: a case study from the Uluguru Mountains. Oryx 46(1):34 44. http://dx.doi.org/10.1017/ $\underline{\mathrm{s} 0030605311001335}$

López-Rodriguez, R., and F. Acevedo-Rosas. 2005. Flood risk zones within the State of Veracruz. Mexican National Water Commission, Veracruz Delegation. Xalapa, Veracruz, Mexico.

Manson, R. H. 2004. Hydrological services and the conservation of Mexican forests. Madera y Bosques 10(1):3-20.

Manson, R., G. Barrantes, and P. Bauche Petersen. 2013. Lecciones de Costa Rica y México para el desarrollo y fortalecimiento de programas de pago por servicios ambientales hidrológicos en América Latina. Pages 245-170 in A. Lara, P. Laterra, R. Manson, and G. Barrantes, editors. Servicios Ecosistémicos Hídricos: Estudios de Caso en América Latina y El Caribe. Valdivia, Chile. Red ProAgua CYTED, Imprenta America.

Martin Persson, U., and F. Alpízar. 2013. Conditional cash transfers and payments for environmental services - a conceptual framework for explaining and judging differences in outcomes. World Development 43:124-137. http://dx.doi.org/10.1016/j. worlddev.2012.10.006

Martínez, M. L., O. Pérez-Maqueo, G. Vázquez, G. CastilloCampos, J. García-Franco, K. Mehltreter, M. Equihua, and R.
Landgrave. 2009. Effects of land use change on biodiversity and ecosystem services in tropical montane cloud forests of Mexico. Forest Ecology and Management 258:1856-1863. http://dx.doi. org/10.1016/j.foreco.2009.02.023

McJannet, D., J. Wallace, P. Fitch, M. Disher, and P. Reddell. 2007. Water balance of tropical rainforest canopies in north Queensland, Australia. Hydrological Processes 21:3473-3484. http://dx.doi.org/10.1002/hyp.6618

Meals, D. W., S. A. Dressing, and T. E. Davenport. 2010. Lag time in water quality response to best management practices: a review. Journal of Environmental Quality 39(1):85-96. http://dx.doi. org/10.2134/jeq2009.0108

Mokondoko, P., R. H. Manson, and O. Pérez-Maqueo. 2016. Assessing the service of water quality regulation by quantifying the effects of land use on water quality and public health in central Veracruz, Mexico. Ecosystem Services 22:161-173. http://dx.doi. org/10.1016/j.ecoser.2016.09.001

Molina, A., G. Govers, V., Vanacker, J. Poesen, E. Zeelmaekers, and F. Cisneros. 2007. Runoff generation in a degraded Andean ecosystem: interaction of vegetation cover and land use. Catena 71:357-370. http://dx.doi.org/10.1016/j.catena.2007.04.002

Muñoz-Piña, C., A. Guevara, J. M. Torres, and J. Braña. 2008. Paying for the hydrological services of Mexico's forests: analysis, negotiations and results. Ecological Economics 65:725-736. http:// dx.doi.org/10.1016/j.ecolecon.2007.07.031

Muñoz-Piña, C., M. Rivera, A. Cisneros, and H. García. 2011. Retos de la focalización del Programa de Pago por los Servicios Ambientales en México. Revista Españ;ola de Estudios Agrosociales y Pesqueros 228(1):87-113.

Muñoz-Villers, L. E., D. R. Geissert, F. Holwerda, and J. J. McDonnell. 2016. Factors influencing stream baseflow transit times in tropical montane watersheds. Hydrology and Earth System Sciences 20(4):1621-1635. http://dx.doi.org/10.5194/ hess-20-1621-2016

Muñoz-Villers, L. E., F. Holwerda, M. S. Alvarado-Barrientos, D. Geissert, B. Marin-Castro, A. Gomez-Tagle, J. J. McDonnell, H. Asbjornsen, T. Dawson, and L. A. Bruijnzeel. 2015. Efectos hidrológicos de la conversión del bosque de niebla en el centro de Veracruz , México. Bosque 36(3):395-407. http://dx.doi. org/10.4067/s0717-92002015000300007

Muñoz-Villers, L., F. Holwerda, M. Gomez-Cardenas, M. Equihua, H. Asbjornsen, L. A. Bruijnzeel, B. E. Marín-Castro, and C. Tobón. 2012. Water balances of old-growth and regenerating montane cloud forests in Central Veracruz, Mexico. Journal of Hydrology 462-463:53-66. http://dx.doi.org/10.1016/ j.jhydrol.2011.01.062

Muñoz-Villers, L. E., and J. López-Blanco. 2008. Land use/cover changes using Landsat TM/ETM images in a tropical and biodiverse mountainous area of central-eastern Mexico. International Journal of Remote Sensing 29(1):71-93. http://dx. doi.org/10.1080/01431160701280967

Muñoz-Villers, L. E., and J. J. McDonnell. 2013. Land use change effects on runoff generation in a humid tropical montane cloud forest region. Hydrology and Earth System Sciences 17:35433560. http://dx.doi.org/10.5194/hess-17-3543-2013 
Muradian, R., M. Arsel, L. Pellegrini, F. Adaman, B. Aguilar, B. Agarwal, E. Corbera, et al. 2013. Payments for ecosystem services and the fatal attraction of win-win solutions. Conservation Letters 6(4):274-279. http://dx.doi.org/10.1111/j.1755-263x.2012.00309. $\underline{\mathrm{x}}$

Nelson, E., S. Polasky, D. J. Lewis, A. J. Plantinga, E. Lonsdorf, D. White, D. Bael, and J. J. Lawler. 2008. Efficiency of incentives to jointly increase carbon sequestration and species conservation on a landscape. Proceedings of the National Academy of Sciences of the United States of America 105(28):9471-9476. http://dx.doi. org/10.1073/pnas.0706178105

Newton, P., E. S. Nichols, W. Endo, and C. A. Peres. 2012. Consequences of actor level livelihood heterogeneity for additionality in a tropical forest payment for environmental services programme with an undifferentiated reward structure. Global Environmental Change 22:127-136. http://dx.doi. org/10.1016/j.gloenvcha.2011.10.006

Nogueira, A., C. A. Martinez, L. L. Ferreira, and C. H. B. A. Prado. 2004. Photosynthesis and water use efficiency in twenty tropical tree species of differing succession status in a Brazilian reforestation. Photosynthetica 42(3):351-356. http://dx.doi. org/10.1023/b:phot.0000046152.05364.77

Orlove, B., and S. C. Caton. 2010. Water sustainability: anthropological approaches and prospects. Annual Review of Anthropology 39:401-415. http://dx.doi.org/10.1146/annurev. anthro.012809.105045

Pagiola, S., A. Arcenas, and G. Platais. 2005. Can payments for environmental services help reduce poverty? An exploration of the issues and the evidence to date from Latin America. World Development 33(2):237-253. http://dx.doi.org/10.1016/j. worlddev.2004.07.011

Paré, L., and P. Gerez. 2012. Al filo del agua: cogestión de la subcuenca del río Pixquiac, Veracruz. Instituto Nacional de Ecología, Mexico City, D.F., Mexico.

Paruelo, J. M. 2012. Ecosystem services and tree plantations in Uruguay: a reply to Vihervaara et al. (2012). Forest Policy and Economics 22:85-88. http://dx.doi.org/10.1016/j.forpol.2012.04.005

Peñuela-Arévalo, L. A., and J. J. Carrillo-Rivera. 2013. Discharge areas as a useful tool for understanding recharge areas, study case: Mexico catchment. Environmental Earth Sciences 68:999-1013. http://dx.doi.org/10.1007/s12665-012-1803-Z

Petheram, L., and B. M. Campbell. 2010. Listening to locals on payments for environmental services. Journal of Environmental Management 91:1139-1149. http://dx.doi.org/10.1016/j.

jenvman.2010.01.002

Pham, T. T., B. M. Campbell, and S. Garnett. 2009. Lessons for pro-poor payments for environmental services: an analysis of projects in Vietnam. Asia Pacific Journal of Public Administration 31:117-133. http://dx.doi.org/10.1080/23276665.2009.10779359

Porras, I., M. Grieg-Gran, and N. Neves. 2008. All that glitters: a review of payments for watershed services in developing countries. Natural Resource Issues No. 11. International Institute for Environment and Development, London, UK.
Postel, S., T. Prugh, R. Costanza, J. H. Cumberland, H. Daly, R. Goodland, and R. B. Norgaard. 1996. Natural capital and human economic survival. Ecological Economics 19:189-189.

Quintero, M., S. Wunder, and R. D. Estrada. 2009. For services rendered? Modeling hydrology and livelihoods in Andean payments for environmental services schemes. Forest Ecology and Management 258:1871-1880. http://dx.doi.org/10.1016/j. foreco.2009.04.032

Reed, M. S. 2008. Stakeholder participation for environmental management: a literature review. Biological Conservation 141 (10):2417-2431. http://dx.doi.org/10.1016/j.biocon.2008.07.014

Robertson, N., and S. Wunder. 2005. Fresh tracks in the forest: assessing incipient payments for environmental services initiatives in Bolivia. Center for International Forestry Research, Bogor, Indonesia.

Rodriguez-Camargo, N. R. 2015. Analisis del costo de oportunidad de la tierra en la subcuenca del Rio Pixquiac, una aproximacion del valor economico de los servicios ambientales hidrologicos como mecanismo para la conservacion. Thesis. Universidad Veracruzano, Xalapa, Mexico.

Saldaña-Herrera, J. D. 2013. Systematization and documentation of local mechanisms for payments for environmental services in Mexico. Final report. Mexico's National Forestry Commission; Mexican Fund for the Conservation of Nature; USAID "Competitive Program in Mexico".

SAS Institute, Inc. 1990. SAS/STAT user's guide, Version 6, Fourth edition. SAS Institute, Inc., Cary, North Carolina, USA.

Scatena, F. N., L. A. Bruijnzeel, P. Bubb, and S. Das. 2010. Setting the stage. Pages 3-13 in L. A. Bruijnzeel, F. N. Scatena, and L. S. Hamilton, editors. Tropical montane cloud forests: science for conservation and management. Cambridge University Press, Cambridge. http://dx.doi.org/10.1017/cbo9780511778384.003

Schellekens, J. 2006. CQ-FLOW: a distributed hydrological model for the prediction of impacts of land-cover change, with special reference to the Rio Chiquito catchment, northwest Costa Rica. Annex 3 to Final Technical Report DFID-FRP Project No. R7991. VU University, Amsterdam, The Netherlands. http:// www.hydrology-amsterdam.nl/researchpages/CostaRica.html

Scott, D. F., L. A. Bruijnzeel, and J. Mackensen. 2005. The hydrological and soil impacts of forestation in the tropics. Pages 622-651 in M. Bonell, and L. A. Bruijnzeel, editors. Forests, water and people in the humid tropics. Cambridge University Press, Cambridge, UK. http://dx.doi.org/10.1017/cbo9780511535666.032

Scott, D. F., and F. W. Prinsloo. 2008. Longer-term effects of pine and eucalypt plantations on streamflow. Water Resources Research 44:WW00A08. http://dx.doi.org/10.1029/2007WR006781

Scullion, J., C. W. Thomas, K. A. Vogt, O. Perez-Maqueo, and M. G. Logsdon. 2011. Evaluating the environmental impact of payments for ecosystem services in Coatepec (Mexico) using remote sensing and on-site interviews. Environmental Conservation 38(4):426-434. http://dx.doi.org/10.1017/ s037689291100052x 
Shapiro-Garza, E. 2013. Contesting the market-based nature of Mexico's national payments for ecosystem services programs: four sites of articulation and hybridization. Geoforum 46:5-15. http://dx.doi.org/10.1016/j.geoforum.2012.11.018

Sierra, R., and E. Russman. 2006. On the efficiency of environmental service payments: a forest conservation assessment in the Osa Peninsula, Costa Rica. Ecological Economics 59 (1):131-141. http://dx.doi.org/10.1016/j.ecolecon.2005.10.010

Silva, L., and D. D. Williams. 2001. Buffer zone versus whole catchment approaches to studying land use impact on river water quality. Water Research 35(14):3462-3472. http://dx.doi. org/10.1016/s0043-1354(01)00062-8

Sommerville, M., E. J. Milner-Gulland, M. Rahajaharison, and J. P. G. Jones. 2010. Impact of a community-based payment for environmental services intervention on forest use in Menabe, Madagascar. Conservation Biology 24(6):1488-1498. http://dx. doi.org/10.1111/j.1523-1739.2010.01526.X

Stadtmüller, T. 1987. Cloud forests in the humid tropics. A bibliographic review. United Nations University, Tokyo, and CATIE, Turrialba, Costa Rica.

Tejeda- Martínez, A. 2005. Panorama of flooding in the State of Veracruz during 2005. Applied Climate Group, Department of Atmospheric Sciences, University of Veracruz, Veracruz, Mexico.

Tejeda- Martínez, A., editor. 2009. Programa Veracruzano ante el Cambio Climático. State Government of Veracruz, Universidad Veracruzana, Instituto National de Ecología, Embajada Británica México.

Townsend, P. V., R. J. Harper, P. D. Brennan, C. Dean, S. Wu, K. R. J. Smettem, and S. E. Cook. 2012. Multiple environmental services as an opportunity for watershed restoration. Forest Policy and Economics 17:45-58. http://dx.doi.org/10.1016/j.forpol.2011.06.008

Van Dijk, A. I. J. M., M. van Noordwijk, I. R. Calder, I. R., L. A. Bruijnzeel, J. Schellekens, N. A. Chappell, J. Smyle, and B. Aylward. 2009. Forest-flood relation still tenuous - comment on 'Global evidence that deforestation amplifies flood risk and severity in the developing world' by Bradshaw, C. J. A., N. S. Sodi, K. S.-H., and B. W. Brook. Global Change Biology 15(1):110-115. http://dx.doi.org/10.1111/j.1365-2486.2008.01708.x

Van Hecken, G., and J. Bastiaensen. 2010. Payments for ecosystem services in Nicaragua: Do market-based approaches work? Development and Change 41:421-444. http://dx.doi.org/10.1111/ j.1467-7660.2010.01644.X

Van Noordwijk, M., B. Leimona, R. Jindal, et al. 2012. Payments for environmental services: evolution toward efficient and fair incentives for multifunctional landscapes. Annual Review of Environment and Resources 37:389-420. http://dx.doi.org/10.1146/ annurev-environ-042511-150526

Vatn, A. 2010. An institutional analysis of payments for environmental services. Ecological Economics 69(6):1245-1252. http://dx.doi.org/10.1016/j.ecolecon.2009.11.018

Verburg, P. H., W. Soepboer, A. Veldkamp, R. Limpiada, V. Espaldon, and S. S. A. Mastura. 2002. Modeling the spatial dynamics of regional land use: the CLUE-S model. Environmental Management 30(3):391-405. http://dx.doi.org/10.1007/s00267-002-2630-
Vertessy, R. A., F. G. R. Watson, and S. K. O’Sullivan. 2001. Factors determining relations between stand age and catchment water balance in mountain ash forests. Forest Ecology and Management 143:13-26. http://dx.doi.org/10.1016/S0378-1127 (00)00501-6

Vihervaara, P., A. Marjokorpi, T. Kumpula, M. Walls, and M. Kamppinen. 2012. Ecosystem services of fast-growing tree plantations: a case study on integrating social valuations with land-use changes in Uruguay. Forest Policy and Economics 14:5868. http://dx.doi.org/10.1016/j.forpol.2011.08.008

Wang, Y., P. Yu, W. Xiong, Z. Shen, M. Guo, Z. Shi, A. Du, and L. Wang. 2008. Water-yield reduction after afforestation and related processes in the semiarid Liupan mountains, northwest China. Journal of the American Water Resources Association 44 (5):1086-1097. http://dx.doi.org/10.1111/j.1752-1688.2008.00238. $\underline{x}$

Wendland, K. J., M. Honzak, R. Portela, B. Vitale, S. Rubinoff, and J. Randrianarisoa. 2010. Targeting and implementing payments for multiple ecosystem services: opportunities for bundling biodiversity conservation with carbon and water services in Madagascar. Ecological Economics 69:2093-2107. http://dx.doi.org/10.1016/j.ecolecon.2009.01.002

Wilson, K., A. Newton, C. Echeverría, C. Weston, and M. Burgman. 2005. A vulnerability analysis of the temperate forests of south central Chile. Biological Conservation 122:9-21. http:// dx.doi.org/10.1016/j.biocon.2004.06.015

Wunder, S. 2006. Payments for environmental services: some nuts and bolts. Center for International Forestry Research (CIFOR), Bogor, Indonesia.

Wunder, S. 2007. The efficiency of payments for environmental services in tropical conservation. Conservation Biology 21(1):4858. http://dx.doi.org/10.1111/j.1523-1739.2006.00559.x

Wunder, S., and M. Alban. 2008. Decentralized payments for environmental services: the cases of Pimampiro and PROFAFOR in Ecuador. Ecological Economics 65:685-698. http://dx.doi. org/10.1016/j.ecolecon.2007.11.004

Wünscher, T., S. Engel, and S. Wunder. 2008. Spatial targeting of payments for environmental services: a tool for boosting conservation benefits. Ecological Economics 65(4):822-833. http://dx.doi.org/10.1016/j.ecolecon.2007.11.014

Yáñez-Arancibia, A., and J. W. Day. 2004. Environmental subregions in the Gulf of Mexico coastal zone: the ecosystem approach as an integrated management tool. Ocean \& Coastal Management 47(11):727-757. http://dx.doi.org/10.1016/j. ocecoaman.2004.12.010

Zadroga, F. 1981. The hydrological importance of a montane cloud forest area of Costa Rica. Pages 59-73 in R. Lal and E. W. Russel, editors. Tropical agriculatural hydrology. John Wiley, New York, USA.

Zhang, L., K. Hickel, W. R. Dawes, F. H. S. Chiew, A. W. Western, and P. R. Briggs. 2004. A rational function approach for estimating mean annual evapotranspiration. Water Resources Research 40:W02502. http://dx.doi.org/10.1029/2003WR002710

Zimmermann, B., and H. Elsenbeer. 2009. The near-surface hydrological consequences of disturbance and recovery: a 
simulation study. Journal of Hydrology 364:115-127. http://dx. doi.org/10.1016/j.jhydrol.2008.10.016

Zimmermann, B., A. Zimmermann, H. L. Scheckenbach, T. Schmid, J. S. Hall, and M. van Breugel. 2013. Towards quantifying the increase of rainfall interception during secondary forest succession. Hydrology and Earth System Sciences 10:7999-8029. 